経 営史 学

性物 压 の 倒泉さ基 近

あ産的北て、泉年

と急大筆、、挹産

い速き綿者両泉地

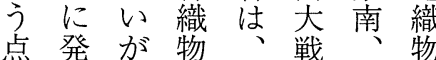

で展、と戦間遠業

あし一毛前期州研

る 無九織期 の 究

。視三物の泉知は

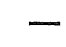

両

大

戦

泉ぎ三 と 泉北多着闌

機な昭並機業四に泉

業い和存業に大進

は存六しをお 機歩

生在た考け業を

北

機

業

産に年地察る地遂

の)

力な以域守個の別

重

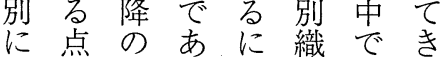

見はわつあ物最た

た泉がたた工も

場 北国とつ場解し

合機の いての明か

三業紡方以経がし

の特製で下のれが

層色品あの実てら、

にでのる点態い、

分あ生。にをた本

割る。産 も注分地稿

で。のち意析域で

き第急乃市ず取

層

性

論

山

大

戦

间

其月

泉

北

秒

業

12

5

け

る

䋨

物

工

場

経

高

動

す注呼戦たささたた

口

な意応前とを。る

わ卞し期考目そ泉

ちへてに无的こ北

き、䘜とでは

松

最は、二しいした乩従

本

と北 綿第。稿来

し 機年織一資

て業代物に料

ににの、的

大はは比戦次制

規重毛重前資約

模虜織 が 期 料 加

貴

典 
織本物つ

物稿生い両 にで産て大

移分のは戦 ○析增次間

$\tau$ 古加第期 いるもにの <織 著 羅 泉 物 ᄂ 紗 北 そ 場い等郡 では泉紡は 個一韯綿 別九戦物織 織 二後の物 物 $\overrightarrow{\text { に }}$ 年は産白 場代紡量条 の加毛加綿 経ら織增た 営一物加 分九の.しで を $\bar{\bigcirc}$ くく 始年産る。特 るにと特産 前、なにの に生旁萡綿 泉の、至布 北ウ 既 $\vec{\bigcirc} の$ 郡工に年他 のイこ代

綿卜のに綿 織が時は亲 物産期綿ル 業地に織 とのそ物 敷 毛 動のが布 織向 発急等 物と展速が 業同のに生 のじ胎発産 生〈動展さ 産綿架守れ 額織見豆毛 唯物䄉 ラ 点。毛物
ろ稿るばた異程泉とに う。変二本い質度北と香

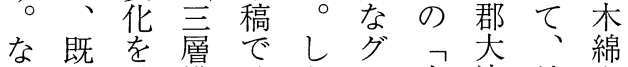
扮に遂構分たル小津綿生 戦げ造析が、規町織産 二残前た守つプ模、物を さかかのるてに工現と行 両れらを中の、分場在毛う 大たそ明間は泉化它織 戦 のら層、北しが泉物産 戦産胎加に機て存大泉地 間地動にあ九業い在津再大 期大加した言のる守市方経 に経見たる。全とるに嫦1

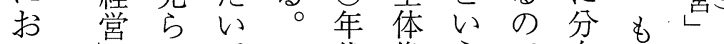

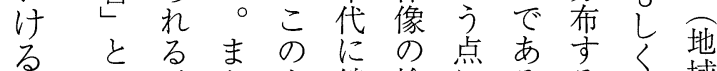
るとる、まのに泉点あ京く地 北小泉、規織証は。毛的 機 規北泉模物は注つが織に

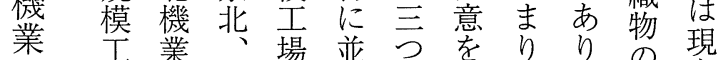
の場のわ委わ行の要、、の在 動綿け分し部守泉そみの 向と織 析て分る北し生和 に物もを毛にのはて痤泉 関泉通織分で生最產市

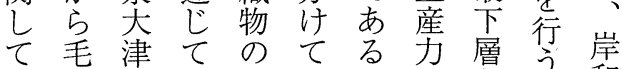
は織市、生行が規とう、和 物は泉産う、模し織男

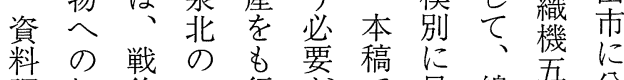
調転後隹行㤎想綿吾分

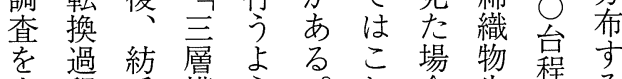
実程秏構う。塔生度当 施に織造に年製産のが

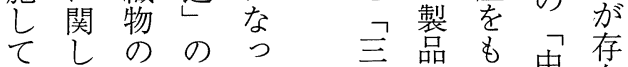

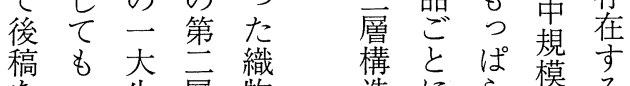

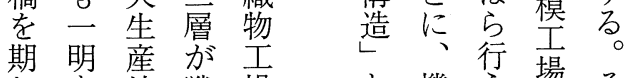

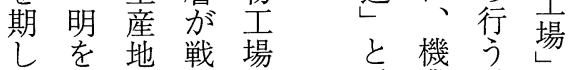
た灯に地戦場等機 い守な期あ灾家織地它

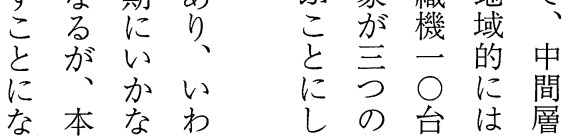


経営史学

泉た発額 以 北。をは上年軍大綿織 $○$ 下恐。打に織た 郡遂綿要に需が織物 ○落慌生ちま物図

の げ織高はの決物の 万、にと産、での 1

こ た物る、増定の生円も金額そ跳生に

ののはに毛加的生産に助解忐れね産よ

よで毛、織しと産はま性禁落以上額つ

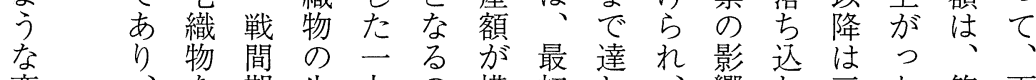

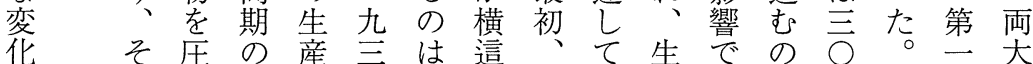

にの倒泉額五 羅い第い産伸は $\bigcirc$ 一次戦

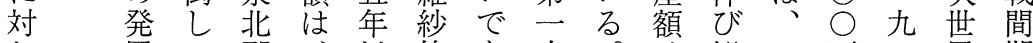

乙 展て 郡、以等あ次。は悩二方界 期

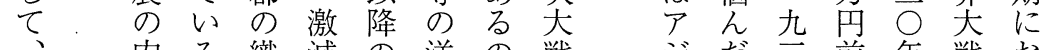

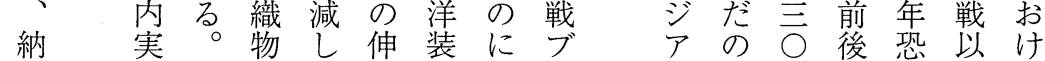

谷はし生たび用対、地が・に慌前る

竹名産綿は毛し公域原三ま期に泉

織戦しは織急織て 期へ因二でには北

物 後、物速物、にに年回は一郡

I に綿金のでの毛拡輸あだ復二ののの

場は織額生あ需織大 出つあし七 織

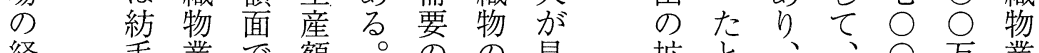

経毛業で額。のの見拡と、万業

営織 が見を結拡生ら 大思当一万而 の

は物発れ凌局大産れを等九時九吕を動

どの展ば駕、がはた挺れの云に下向

の 一守、古最あ着。子る輸七ま回を

よ大る綿る盛つ実そにに。出つでつ概

う産か織ま期たにの順し依昭落て括

に地た物でに二増後調か存和ちいし

対とわ業には九加に江し度三达たて

応 ら

乙 るで毛つ産 三て 九 復金約年が、き

い背毛物い

つ織業る

た発物は。四のし代 九禁で恐三大

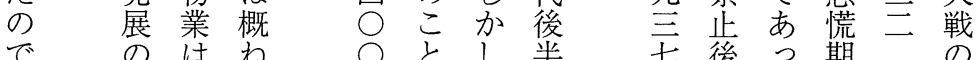

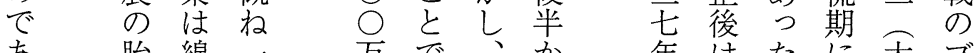

あ 胎綿一 万で、かだ

万動織 $\bigcirc$ 円 あ泉ら の、泉も正

うを物 $\cdots$ 以り北言 ピ 積 北こ二

か、上業— 上郡 $\overrightarrow{0}$ 上極のの二期

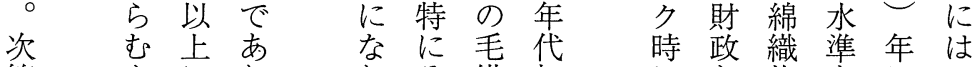

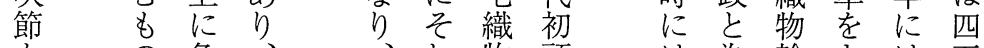

か の急、、れ物頭、㤫輸キは五

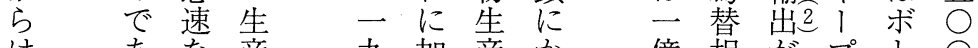

はあな産九加産か 億相がプト○ 


\section{生産額(円)}

図 1 泉北郡における織物生産額推移

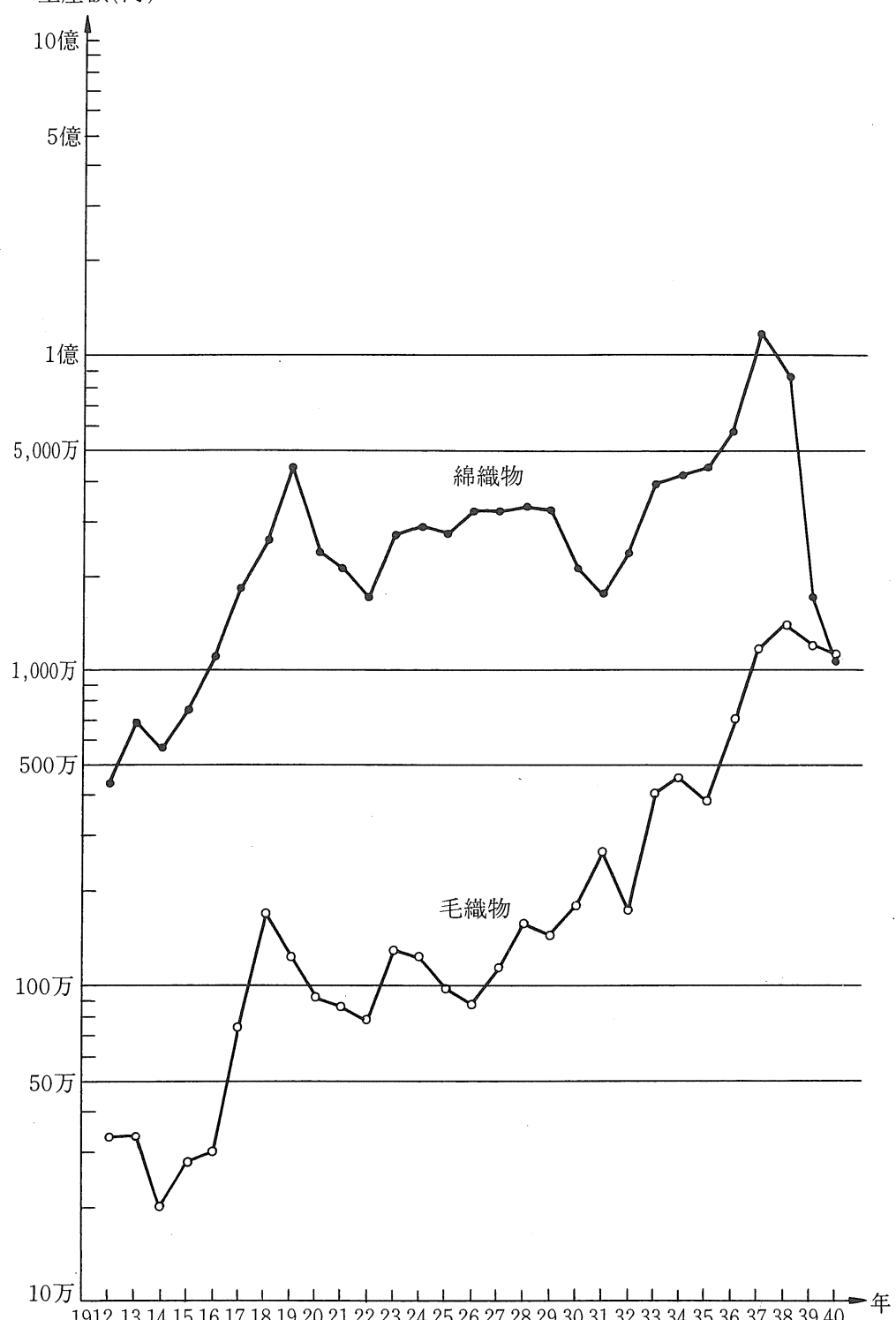
資料：『大阪府統計書』 
経 営史 学

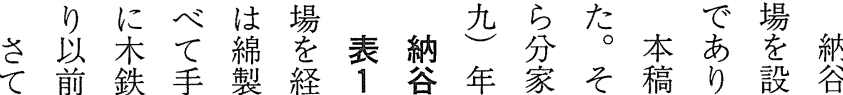
て、前鉄手製経 1 谷年家そ稿り設谷 一変製機紋し 納織現独以取織し が 九わ力を敷て谷物在立前り物た織

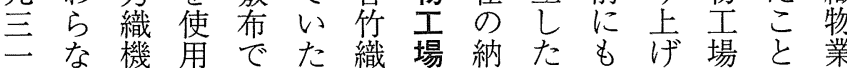
年い㠰しあ頃物の谷の納る設にに ま。計てつ住王竹で谷納立端従 で女复いた場場毛 あ、竹谷かを事 は只四た職の規織る五松竹ら発声 納地使力立 は場等式工父物 ばる出よ

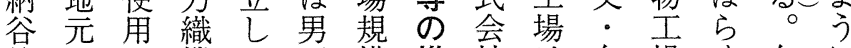
竹のさ機て工模推社は久場く久に 織女孜納三等移の初吉はは吉な 物性、咳名のにあ女の、半はる 工で動始竹推つるはも 場、等 ま織女移い場本々九半在の の歩とる物工劣て所家で三士心は

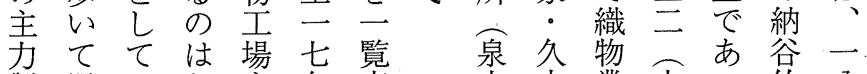
製通五お者表吉吉業大つ竹八 品勤馬そ設のに津のに正た毛八 はで力ら立計し市も従二と織六

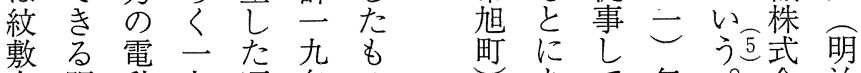
布距動九頃名の沟 あ゙離機示奆でで つ農使年るりるる転が染一 長

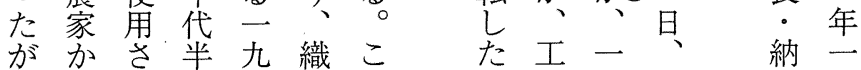
がかさ半九織こ 同採て頃西はにのの蒠寿月 以年用いる゙年すする

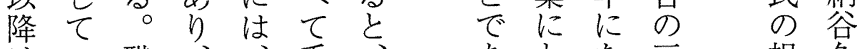
はい職、手、市市な祖久 紋を 敷 は 布のや二はをが にこは元三使父 加亡り年主用。 えで云に名し 久 綿る名名木、主の 毛。程 製や要 も 交度なはなと 織禼らり製で て吉松竹 た 一年より歳 九齢 つ本 納 的七来谷 四な設は久 理立自織 昭胄妾作物 和かれ農工 
第26巻 第 4 号

表 1 納谷竹織物工場の工場規模等の推移

\begin{tabular}{|c|c|c|c|c|c|c|}
\hline \multirow{2}{*}{ 年 次 } & \multicolumn{2}{|c|}{ 職工数 (人) } & \multirow{2}{*}{ 織 } & \multirow{2}{*}{ 動 力 } & \multirow{2}{*}{ 製品 } & \multirow{2}{*}{ 依拠資料 } \\
\hline & 男工 & 女工 & & & & \\
\hline $\begin{array}{c}\text { 大正 } 9 \text { 年 } \\
(1920)\end{array}$ & 2 & 17 & 手織機 & 原動機なし & 綿布, 敷布 & (1) \\
\hline $\begin{array}{c}\text { 大正12年 } \\
(1923)\end{array}$ & \multicolumn{2}{|c|}{ (23) } & 手織機 & 原動機なし & $\begin{array}{l}\text { 紋敷布, } \\
\text { 卓上掛 }\end{array}$ & (2) \\
\hline $\begin{array}{c}\text { 昭和 } 2 \text { 年 } \\
\text { (1927) }\end{array}$ & \multicolumn{2}{|c|}{$2{ }^{2} 16$} & $\begin{array}{l}\text { 大津式木製力織機 } \\
6 \text { 台, 南部式木鉄 } \\
\text { 混製力織機 } 8 \text { 台 } \\
\text { 計 } 14 \text { 台 }\end{array}$ & $\begin{array}{l}\text { 電動機 } 5 \text { 馬力 } \\
\text { (南海電車より) }\end{array}$ & $\begin{array}{l}\text { 紋敷布, } \\
\text { 綿毛布 }\end{array}$ & (3) \\
\hline $\begin{array}{c}\text { 昭和 } 7 \text { 年 } \\
(1932)\end{array}$ & 2 & 20 & 力織機15台 & & $\begin{array}{l}\text { 紋敷布, } \\
\text { 毛布, ラシャ }\end{array}$ & (4) \\
\hline $\begin{array}{c}\text { 昭和10年 } \\
(1935)\end{array}$ & & & $\begin{array}{l}\text { 大隈式鉄製力織機 } \\
\text { 他 } 40 \text { 台 }\end{array}$ & & $\begin{array}{l}\text { 毛布, ラシャ } \\
\text { 紋敷布 }\end{array}$ & (5) \\
\hline $\begin{array}{c}\text { 昭和15年 } \\
\text { (1940) }\end{array}$ & 2 & & $\begin{array}{l}\text { 大隈式鉄製力織機 } \\
\text { 他 } 40 \text { 台 }\end{array}$ & $\begin{array}{l}\text { 電動機その他 } \\
\text { 33馬力 }\end{array}$ & 毛布, ラシャ & (6) \\
\hline
\end{tabular}

依拠資料 (1) 『大正10年版工場通覧』, 岸原吉次郎『大阪府泉北郡大津機業研究』, 納谷寿明氏より筆 者きとり (1989年 2 月 23 日実施)

（2）大阪府産業部工務課編『大阪府全管工業一覧』（1923年12月末時点調査）

(3) 『昭和 2 年 3 月現在泉北郡織物同業組合組合員名簿』(泉州織物工業協同組合所蔵)

(4) 『昭和 7 年度大阪府工業年報』, 紡織雑誌社『紡織要覧』(1932年)

（5）『納谷竹織物工場新築控』，川上金蔵『泉州名鑑巻 2 』(夕刊関西日日新聞社，1938年), 納谷寿明氏より筆者ききりり(1989年 2 月 23 日実施)

(6) 『昭和15年12月末現在大津町会社工場調』(泉大津市役所所蔵)，石塚博章氏より筆者き きとり(1989年 9 月21日実施)

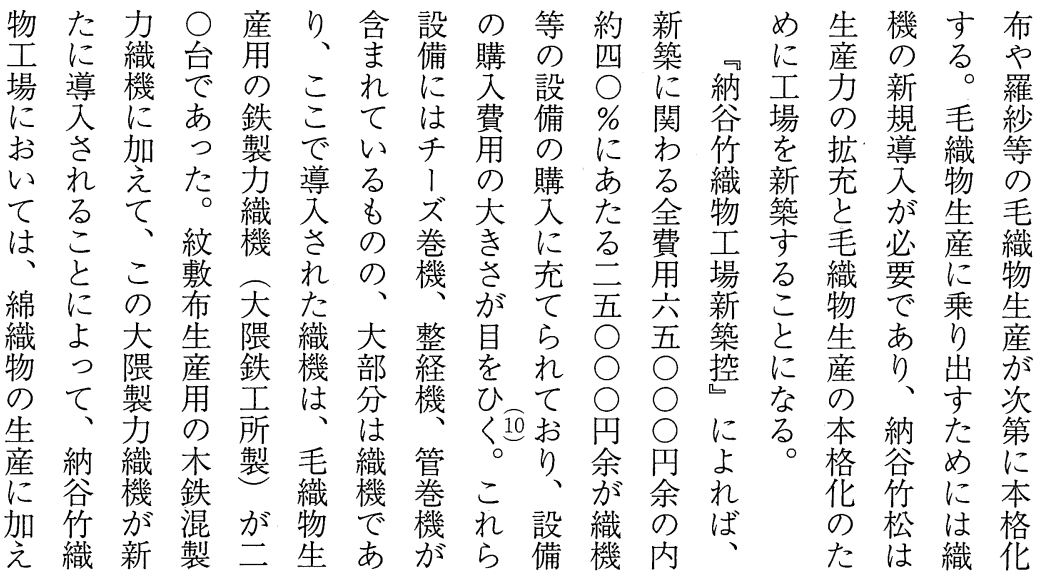


ても っ九名上谷があた格物製大い製工織 た云前要 竹全つ化生品津る妿場物

と $\bigcirc$ 後守織体たこ方産は式。織はの 兵代とに物 の泉こ方北でと伸織機の織職産 る 後大場割郡、心張物 ・四導 I 加 で半き泉はを大泉う期生南 ○学数開 あかく北上占津北納で地部台さ始 万ら変郡位め町郡谷あに式の狆約さ

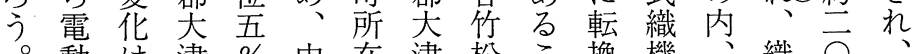
動 は津 \% 中在津松こ換機、織 $\bigcirc$ 、 機し町に小の町の方しで半機名製 がな有属商工に経をてあ数数と品 使い数し吉場お営差いりのは以多 用もの致をけ戦しつ、三前様 さの納泉にる略引た大 $\vec{\bigcirc}$ 前と化 れの谷北典所こはい。隈台か大出 竹郡型有の みて 後製がらきき可 そ織織大的織新ごも述吕毛使く能 れ機物津な 機 工 と、織織角変

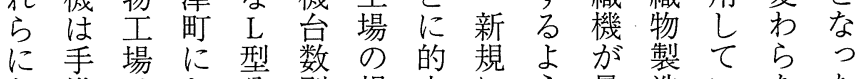
と織はお分別規中にう最造いなた も機、け布に模し導にも角たいの なか職るをヒをた文、性のをむ゙で

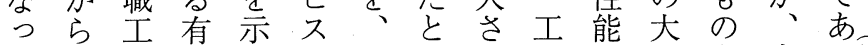

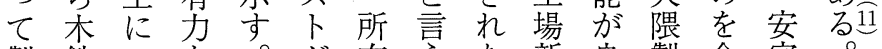
製鉄つな。グ, 有えた新良製合宅 品混い土新 ラ織よ力設占力わ商 も製て場築么機う織後つ織せ会 綿力はでさに台。機のた機るの 織織設あれ表数少期と仲 物機立つた守に生末心残四介 かを当た 工と立利う焉り らへ初と場、性益云台毛 毛て 織鉄り六所有検高伸し台な物 物製二る有織討くびて がり角

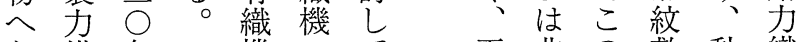
と織名機—て 工非の敷 動 織 生機程台了扮場常力布力機 産が度数九こ織的もと の中驾台う 新急機綿主し ウ心男四ま。築速の布至て 工に工去納 $○$ 導製馬有 イな台の谷毛あ告力名 卜り名年小竹織りに用にで が、市規織物、よの拡あ

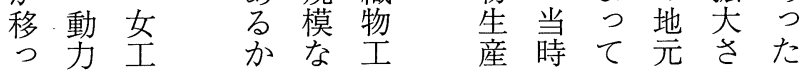


(参考)

\begin{tabular}{|c|c|c|c|}
\hline 期末利潤 & $\begin{array}{l}\text { 期末利潤 } \\
\text { 増加率 } \%\end{array}$ & $\begin{array}{l}\text { 自己資本 } \\
\text { 比率 } \%\end{array}$ & $\begin{array}{l}\text { 売上債権対 } \\
\text { 買入債務比率\% }\end{array}$ \\
\hline 5,921 & - & (n.a.) & 510.8 \\
\hline 8,268 & 39.6 & (n.a.) & 273.3 \\
\hline 8,712 & 5.4 & (n.a.) & - \\
\hline 6,023 & -30.9 & (n.a.) & 781.7 \\
\hline 7,178 & 19.2 & (n.a.) & 637.7 \\
\hline 11,529 & 60.6 & (n.a.) & 235.3 \\
\hline 15,364 & 33.3 & (n.a.) & 167.8 \\
\hline 20,442 & 33.0 & (n.a.) & 503.6 \\
\hline 23,688 & 15.9 & (n.a.) & 74.6 \\
\hline 26,482 & 11.8 & (n.a.) & 46.4 \\
\hline 21,039 & -20.6 & (n.a.) & 1142.5 \\
\hline 21,023 & -0.1 & (n.a.) & 682.7 \\
\hline 19,358 & -7.9 & (n.a.) & 282.3 \\
\hline 18,809 & -2.8 & (n.a.) & 181.1 \\
\hline 16,886 & -10.2 & (n.a.) & 1522.8 \\
\hline 16,238 & -3.8 & (n.a.) & - \\
\hline 11,199 & -31.0 & (n.a.) & 343.4 \\
\hline 18,139 & 62.0 & (n.a.) & 137.6 \\
\hline 28,633 & 57.9 & (n.a.) & 241.2 \\
\hline 42,122 & 47.1 & (n.a.) & 151.5 \\
\hline 46,046 & 9.3 & 95.8 & 220.9 \\
\hline 52,482 & 14.0 & 97.8 & 233.1 \\
\hline 42,704 & -18.6 & 97.5 & 290.0 \\
\hline 51,605 & 20.8 & 92.2 & 128.3 \\
\hline 56,990 & 10.4 & 96.3 & 195.2 \\
\hline 88,165 & 54.7 & 90.9 & 195.8 \\
\hline 85,212 & -3.3 & 96.2 & 311.1 \\
\hline 92,314 & 8.3 & 87.6 & 162.7 \\
\hline 66,137 & -28.4 & 95.0 & 167.0 \\
\hline 128,547 & 94.4 & 82.2 & 99.8 \\
\hline 156,122 & 21.5 & 93.4 & 219.8 \\
\hline
\end{tabular}

潤増加率は対前期増加率である。

以下は四捨五入した。

権対買入債務比率= (売掛金十受取手形 $) \times 100 \div$ (買掛金十 形) で算出。数值が小さい方が, 売り手から大きな信用を れていると考えられる。

年 五 場

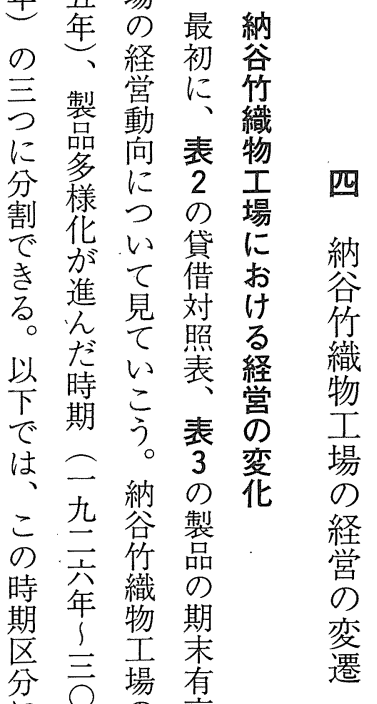

た戦も 三 当打二撃 こ I

に年の高

従年経 推

つ、営移

て毛は二

各織、覧

々 物 綿 表

のの織

時 生 物 表

期 産 の 4

にが生の

お主 産 取

言の以秋つ加年場五

わ反ほ以てらはが年

れ動ど降いよ、設

て恐超のるう泉立

お慌繁 震觉苝さ

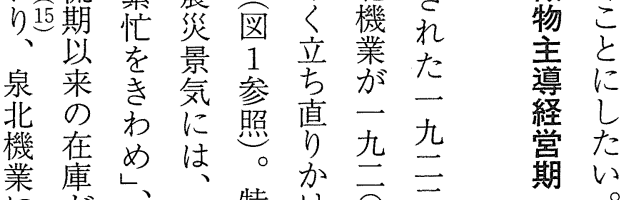

け軸が引

にが、、特け $\vec{\bigcirc}$ 二

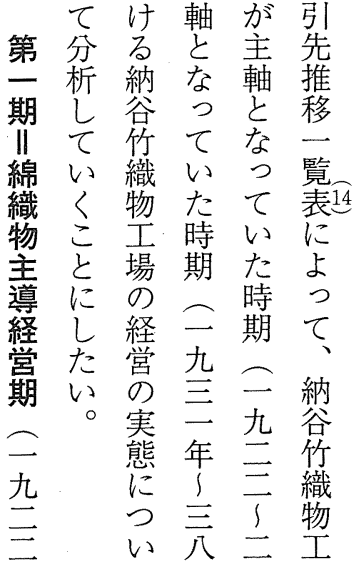


経 営 史 学

表 2 納谷竹織物工場の貸借対照

\begin{tabular}{|c|c|c|c|c|c|c|c|c|}
\hline \multirow{2}{*}{ 年 次 } & \multicolumn{5}{|c|}{ 資 } & \multicolumn{3}{|c|}{ 負債 - 資本 } \\
\hline & 製品 & 原糸 & 売掛金 & 預金 & 資産合計 & 未払金 & 借入金 & 負債合計 \\
\hline 1922年全 & 1,277 & 3,941 & 482 & 472 & 6,171 & 250 & 0 & 250 \\
\hline 23年上 & 683 & 3,615 & 2,155 & 2,065 & 8,518 & 250 & 0 & 250 \\
\hline 23年下 & 1,522 & 5,352 & 664 & 1,174 & 8,712 & 0 & 0 & 0 \\
\hline 24年上 & 1,173 & 3,732 & 2,115 & 914 & 7,933 & 150 & 1,760 & 1,910 \\
\hline 24年下 & 1,594 & 3,101 & 1,462 & 1,271 & 7,428 & 250 & 0 & 250 \\
\hline 25年上 & 3,830 & 3,789 & 2,270 & 3,267 & 13,156 & 1,628 & 0 & 1,628 \\
\hline 25年下 & 3,176 & 4,396 & 2,564 & 7,121 & 17,257 & 1,893 & 0 & 1,893 \\
\hline 26年上 & 1,511 & 4,073 & 6,731 & 8,428 & 20,742 & 300 & 0 & 300 \\
\hline 26年下 & 1,942 & 5,357 & 6,198 & 12,793 & 26,289 & 2,601 & 0 & 2,601 \\
\hline 27年上 & 2,041 & 6,914 & 7,677 & 14,248 & 30,880 & 4,398 & 0 & 4,398 \\
\hline 27年下 & 5,465 & 5,051 & 9,329 & 1,672 & 21,517 & 478 & 0 & 478 \\
\hline 28年上 & 6,141 & 6,141 & 7,375 & 2,266 & 21,922 & 899 & 0 & 899 \\
\hline 28年下 & 3,3 & 4,111 & 6,136 & 6,960 & 20,538 & 1,180 & 0 & 1,180 \\
\hline 29年上 & 3,897 & 8,426 & 9,607 & 67 & 21,997 & 2,152 & 1,036 & 3,188 \\
\hline 29年下 & 3,685 & 4,613 & 6,920 & 1,910 & 17,128 & 242 & 0 & 242 \\
\hline 30年上 & 3,515 & 2,950 & 5,502 & 4,271 & 16,238 & 0 & 0 & 0 \\
\hline 30年下 & 3,598 & 4,599 & 4,337 & 623 & 13,158 & 1,048 & 911 & 1,959 \\
\hline 31年全 & 5,019 & 5,539 & 8,692 & 2,537 & 21,787 & 3,648 & 0 & 3,648 \\
\hline 32 年上 & 36,036 & 5,238 & 1,908 & 459 & 43,640 & 14,939 & 68 & 15,007 \\
\hline 32年下 & 10,562 & 20,880 & 13,733 & 3,917 & 49,092 & 6,970 & 0 & 6,970 \\
\hline 33年上 & 24,131 & 18,632 & 12,379 & 1,829 & 56,971 & 10,925 & 0 & 10,925 \\
\hline 33年下 & 12,836 & 17,274 & 22,292 & 5,587 & 57,989 & 5,507 & 0 & 5,507 \\
\hline 34年全 & 16,921 & 18,631 & 10,987 & 2,564 & 49,103 & 5,836 & 563 & 6,399 \\
\hline 35年上 & 26,983 & 35,422 & 9,925 & 303 & 72,632 & 21,028 & 0 & 21,028 \\
\hline 35年下 & 19,009 & 23,242 & 19,094 & 5,382 & 66,728 & 9,738 & 0 & 9,738 \\
\hline 36年上 & 48,780 & 40,633 & 17,607 & 6,055 & 113,075 & 24,911 & 0 & 24,911 \\
\hline 36年下 & 30,999 & 29,699 & 22,739 & 11,740 & 95,178 & 9,966 & 0 & 9,966 \\
\hline 37年上 & 57,433 & 37,460 & 31,818 & 899 & 127,610 & 35,296 & 0 & 35,296 \\
\hline 37年下 & 22,056 & 28,650 & 25,346 & 3,291 & 79,343 & 13,206 & 0 & 13,206 \\
\hline 38年上 & 53,926 & 90,772 & 33,218 & 4,664 & 182,581 & 54,034 & 0 & 54,034 \\
\hline 38年下 & 39,020 & 78,042 & 48,432 & 8,383 & 173,876 & 17,754 & 0 & 17,754 \\
\hline 資料：『大正 & 淇納谷 & 戒物工士 & $\begin{array}{l}\text { 算簿』, } \\
\text { 算簿』 }\end{array}$ & Pi & 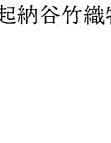 & 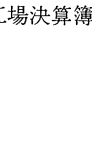 & & $\begin{aligned} 1 & : \text { 期末利 } \\
2 & \text { : 小数点 } \\
3 & \text { : 売上債 } \\
& \text { 支払手 } \\
& \text { 与えら }\end{aligned}$ \\
\hline
\end{tabular}

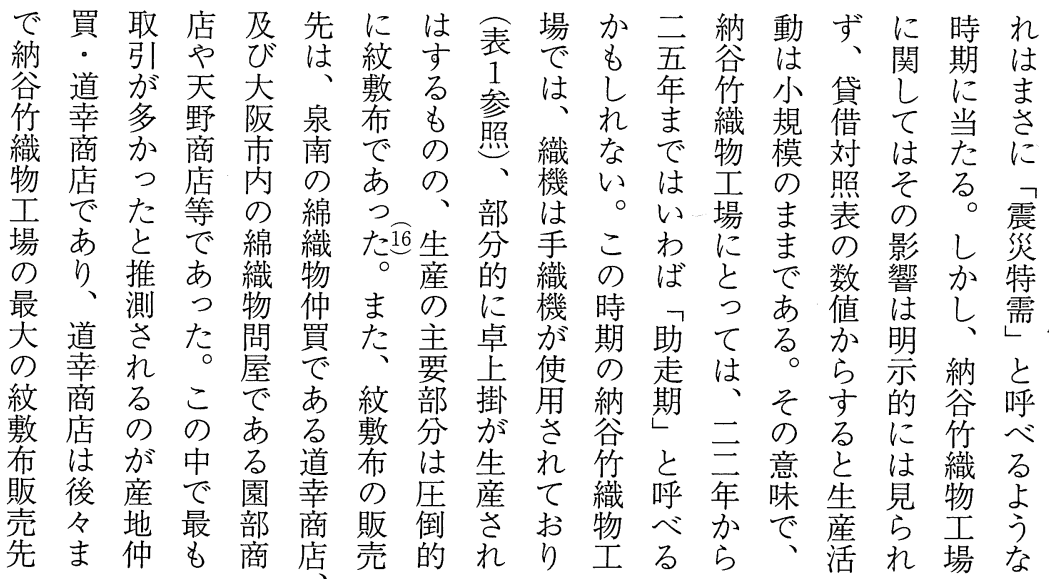


第26巻 第 4 号

表 3 納谷竹織物工場における製品期末有高推移

(単位: 円)

\begin{tabular}{|c|c|c|c|c|c|c|c|}
\hline 年次 & 期 & 紋敷布 & 卓上掛 & 肩 掛 & 毛 布 ${ }^{\mathrm{a}}$ & 羅＼cjkstart紗 & 有高合計 \\
\hline 1922 & 全 & 986 & 309 & 0 & 0 & 0 & 1,295 \\
\hline 1923 & 上 & 530 & 153 & 0 & 0 & 0 & 683 \\
\hline 1923 & 下 & 1,346 & 176 & 0 & 0 & 0 & 1,522 \\
\hline 1924 & 上 & 1,134 & 39 & 0 & 0 & 0 & 1,173 \\
\hline 1924 & 下 & 1,380 & 214 & 0 & 0 & 0 & 1,594 \\
\hline 1925 & 上 & 2,797 & 513 & $520^{b}$ & 0 & 0 & 3,830 \\
\hline 1925 & 下 & 2,969 & 207 & 0 & 0 & 0 & 3,176 \\
\hline 1926 & 上 & 1,510 & 1 & $1,515^{\mathrm{c}}$ & 0 & 0 & 3,026 \\
\hline 1926 & 下 & 1,773 & 169 & 0 & 0 & 0 & 1,942 \\
\hline 1927 & 上 & 1,251 & 0 & $790^{\mathrm{d}}$ & 0 & 0 & 2,041 \\
\hline 1927 & 下 & 3,589 & 0 & 0 & 1,876 & 0 & 5,465 \\
\hline 1928 & 上 & 3,930 & 0 & 1,038 & 1,177 & 0 & 6,145 \\
\hline 1928 & 下 & 3,331 & 0 & 0 & 0 & 0 & 3,331 \\
\hline 1929 & 上 & 3,653 & 0 & 245 & 0 & 0 & 3,897 \\
\hline 1929 & 下 & 3,685 & 0 & 0 & 0 & 0 & 3,685 \\
\hline 1930 & 上 & 3,515 & 0 & 0 & 0 & 0 & 3,515 \\
\hline 1930 & 下 & 3,481 & 117 & 0 & 0 & 0 & 3,598 \\
\hline 1931 & 全 & 3,088 & 340 & 0 & 372 & 1,214 & 5,014 \\
\hline 1932 & 上 & 686 & 0 & 0 & 7,292 & 28,058 & 36,036 \\
\hline 1932 & 下 & 1,479 & 0 & 0 & 3,236 & 5,848 & 10,562 \\
\hline 1933 & 上 & 1,530 & 0 & 0 & 4,937 & 17,665 & 24,131 \\
\hline 1933 & 下 & 4,227 & 0 & 0 & 2,310 & 6,300 & 12,836 \\
\hline 1934 & 全 & 5,687 & 0 & 0 & 3,051 & 8,183 & 16,921 \\
\hline 1935 & 上 & 4,272 & 0 & 0 & 5,085 & 17,626 & 26,983 \\
\hline 1935 & 下 & 5,974 & 0 & 0 & 930 & 12,016 & 18,919 \\
\hline 1936 & 上 & 5,923 & 0 & 0 & 2,477 & 40,380 & 48,780 \\
\hline 1936 & 下 & 4,766 & 0 & 0 & 681 & 25,552 & 30,999 \\
\hline 1937 & 上 & 3,631 & 0 & 0 & 156 & 53,646 & 57,433 \\
\hline 1937 & 下 & 2,989 & 0 & 0 & 3,117 & 15,950 & 22,056 \\
\hline 1938 & 上 & 155 & 0 & 0 & 5,255 & 48,516 & 53,926 \\
\hline 1938 & 下 & 333 & 0 & 0 & 7,147 & 31,540 & 39,020 \\
\hline
\end{tabular}

資料：『大正 11 年起納谷竹織物工場決算簿』, 『昭和 3 年起納谷竹織物工場決算簿』, 『昭和 7 年起納 谷竹織物工場決算簿』

注：(1) 1935年の上半期の貸借対照表には, 毛布 1,204 枚 ( 5,085 円15錚)のうち輸出向けが736.枚 $(3,465$ 円 55 銭)，内地向け468枚（1,620円60銭）の記述がある。

(2) $1922 ， 31 ， 34$ 年は上半期，下半期別に決算がなされていない。

表内注 $\mathrm{a}$ : 毛布生地を含む。

$\mathrm{b} ：$ 半完成品であって，整理加工前の肩掛である。

c：製織を委託された貨織であり，製織貢のみである。

$\mathrm{d} ：$ 半完成品である。 
経 営史 学

表 4 納谷竹織物工場における取引先の推移

\begin{tabular}{|c|c|c|c|}
\hline 項 目 & $\begin{array}{c}\text { 綿織物主導経営期 } \\
\quad(1922 ２ 5 \text { 年 })\end{array}$ & $\begin{array}{c}\text { 製品多様化経営期 } \\
\text { (1926～30年) }\end{array}$ & $\begin{array}{c}\text { 毛織物主導経営期 } \\
\quad(1931 \text { - 38年) }\end{array}$ \\
\hline $\begin{array}{c}\text { 製 品 } \\
\text { (太字は主 } \\
\text { 要製品) }\end{array}$ & $\begin{array}{l}\text { 紋敷布 } \\
\text { 綿織卓上掛 } \\
\text { 綿織肩肩掛 }\end{array}$ & $\begin{array}{l}\text { 紋敷布 } \\
\text { 綿毛布 } \\
\text { 綿織肩掛 } \\
\text { 混綿毛布 }\end{array}$ & $\begin{array}{l}\text { 羅紗 } \\
\text { 混綿毛布 } \\
\text { 紋敷布 }\end{array}$ \\
\hline $\begin{array}{l}\text { 製品販売先 } \\
\text { [ ]内は販 } \\
\text { 売製品 } \\
\text { (太字はウ } \\
\text { エイトの大 } \\
\text { きいもの) }\end{array}$ & $\begin{array}{c}\text { 綿織物の販売 } \\
\text { [紋敷布等の綿織物] } \\
\text { - 泉州の綿織物仲買 } \\
\text { 道幸久治郎商店 } \\
\text { (泉南郡佐野町) } \\
\text { - 大阪市内の綿織物問屋 } \\
\text { 園部豊太郎商店 } \\
\text { 川島慶太郎商店 } \\
\text { 天野金太郎商店 } \\
\text { (3 店とも大阪市東区) }\end{array}$ & $\begin{array}{l}\text { 製品販売先の多様化 } \\
\text { [紋敷布等の綿織物] } \\
\text { 道幸商店 } \\
\text { 園部商店 } \\
\text { 川自商店 } \\
\text { 天野商店, に加之 } \\
\text { 江守織物合資会社 } \\
\text { (大阪市西区) } \\
\text { [毛布等] } \\
\text { - 泉州の織物仲買 } \\
\text { 横山二郎商店 } \\
\text { (泉北郡大津町) } \\
\text { ・大阪市内の織物問屋 } \\
\text { 又一商店 } \\
\text { (大阪市東区) }\end{array}$ & 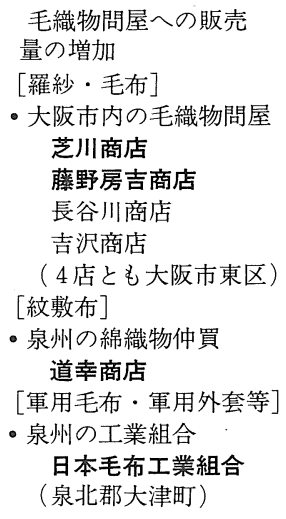 \\
\hline $\begin{array}{c}\text { 原糸購入先 } \\
\text { (太字はウ } \\
\text { エイのの大 } \\
\text { きいもの) }\end{array}$ & $\begin{array}{l}\text { [綿糸 }] \\
\text { - 泉州の綿糸仲買 } \\
\text { 神谷商店 } \\
\text { (堺市) } \\
\text { 兽根勝吉次郎商店 } \\
\text { 小川常治郎商店 } \\
\text { (ともに泉北郡大津町) }\end{array}$ & $\begin{array}{l}\text { [綿糸] } \\
\text { ・大阪市内の綿糸問屋 } \\
\text { 岩田惣三郎商店 } \\
\text { 竹中商店 } \\
\text { (ともに大阪市東区) } \\
\text { - 泉州の綿糸仲買 } \\
\text { 曽根勝吉次郎商店 } \\
\text { (泉北郡大津町) } \\
\text { [毛糸] } \\
\text {-東京の中小毛系紡績 } \\
\text { 吉田紡績 } \\
\text { (東京市千䭾ヶ谷) }\end{array}$ & 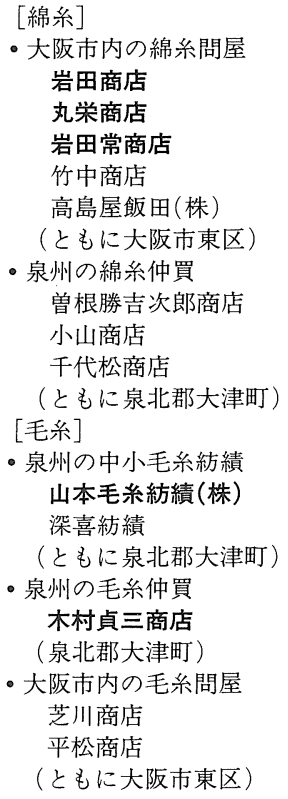 \\
\hline
\end{tabular}




\begin{tabular}{|c|c|c|c|}
\hline 項 目 & $\begin{array}{c}\text { 綿織物主導経営期 } \\
(1922 \text { 25年) }\end{array}$ & $\begin{array}{c}\text { 製品多様化経営期 } \\
\text { (1926 30年) }\end{array}$ & $\begin{array}{c}\text { 毛織物主導経営期 } \\
\quad(1931 \text { 38年) }\end{array}$ \\
\hline $\begin{array}{l}\text { 付属加工 } \\
\text { (太字はウ } \\
\text { エイトの大 } \\
\text { きいもの) }\end{array}$ & $\begin{array}{l}\text { [晒白] } \\
\text { 大大阪市内の工場 } \\
\text { 辻阪晒工場 }\end{array}$ & $\begin{array}{l}\text { [晒白 }] \\
\text { ・大阪市内の工場 } \\
\text { 辻阪晒工場 } \\
\text { - 泉州の工場 } \\
\text { 大津織物仕上会社 } \\
\text { 小山商店, 等 } \\
\text { (ともに泉北郡大津町) } \\
\text { [起毛 }] \\
\text { - 泉州の工場 } \\
\quad \text { 大津織物仕上会社 } \\
\text { [紋紙] } \\
\text { 泉州の工場 } \\
\text { 棚橋紋紙工場 }\end{array}$ & 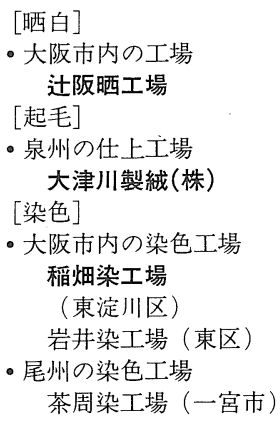 \\
\hline $\begin{array}{l}\text { 取引銀行 } \\
\text { (太字はウ } \\
\text { エイトの大 } \\
\text { きいもの) }\end{array}$ & $\begin{array}{l}\text { - 泉州の銀行 } \\
\text { 和泉銀行 } \\
\text { 和泉貯蓄銀行 }\end{array}$ & $\begin{array}{l}\text { - 泉州の銀行 } \\
\text { 和泉銀行 } \\
\text { 和泉貯蓄銀行 } \\
\text { 大津信用組合 } \\
\text { ・その他の地方銀行 } \\
\text { 尾州銀行 }\end{array}$ & $\begin{array}{l}\text { - 泉州の銀行 } \\
\text { 和泉銀行 } \\
\text { 大津信用組合 } \\
\text { - 都市銀行 } \\
\text { 住友銀行難波支店 } \\
\text { 鴻池銀行 } \\
\downarrow \\
\text { 三和銀行久太郎町支店 }\end{array}$ \\
\hline
\end{tabular}

資料：『大正12年起納谷竹織物工場決算簿』, 『昭和 2 年起納谷竹織物工場決算簿』, 『昭和 7 年起納谷竹織 物工場決算簿』, 『昭和 11 年納谷竹織物工場売原簿』, 『昭和 12 年納谷竹織物工場売原簿』, 『昭和 11 ～12年納谷竹織物工場買原簿』, 『納谷竹織物工場取引先住所録』, 『納谷竹織物工場銀行勘定簿』, 『日本綿糸布要覽』(大阪綿糸商同盟会, 1927年), 『日本紡織品便覧』（大阪綿布商同盟会, 1934年), 岸原吉次郎『大阪府泉北郡大津機業研究』(大阪商科大学卒業実地調査, 1920年)，『深喜毛織百年 史』(1990年)，伊賀上万次郎他『大津町誌』(1932年)，中澤米太郎『泉州繁栄記一銀行編一』(1977 年)，拙稿「反動恐慌期加ら昭和期の泉州綿毛布工業における同業者組織の機能一泉北郡織物同 業組合の限界・改組と日本毛布敷布工業組合の機能一」( ${ }^{\mathbb{P}}$ 大阪大学経済学』, 第38巻第 $3 \cdot 4$ 号合 併号，1989年）

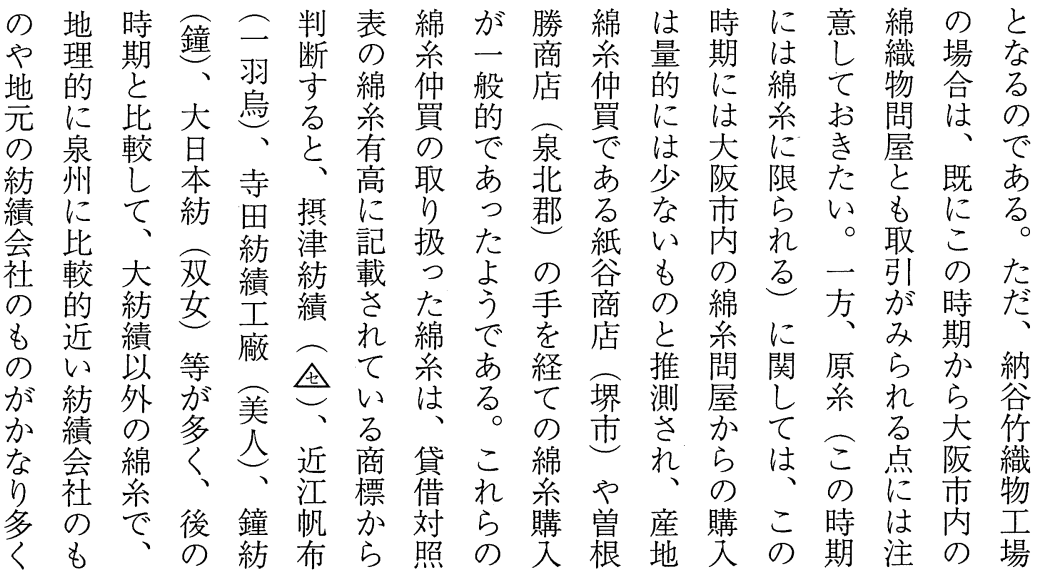


経 営 史 学

撃を直払銀年わ方 あ撃い泉は、て ず信て 期ま谷沓依要和全

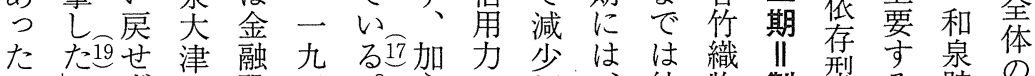

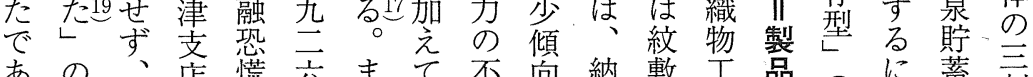

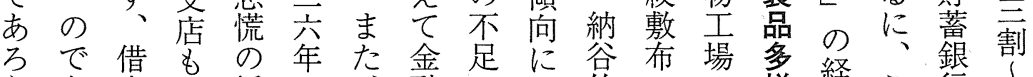
うあ金活煽に、融の市竹のの様営こ行四 しる。動りは近恐たつ織生経华喜の゙晆営割

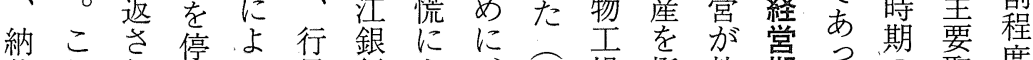

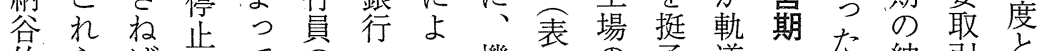
竹らばして の つつ機 2 の子道つ納引 引

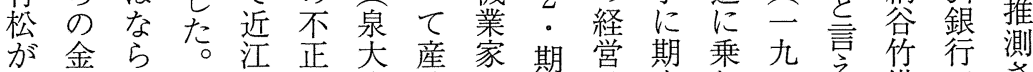

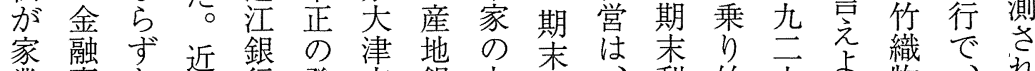
業事々江行 登支銀大利、利始六少物、狆

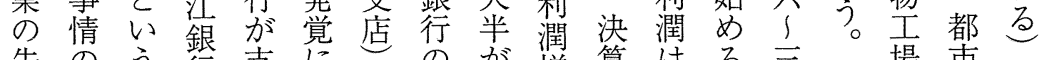

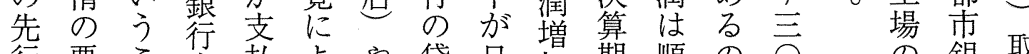
行悪こ泉払よや貸 日加期順の $○$ の 銀 取

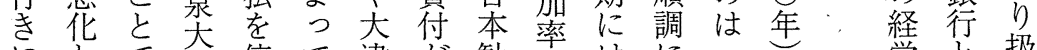
にとで津停て 津㤎勧のはに二営と扱 不泉被支止大銀消業欄黑拡九皇尘わ 安北害店 ᄂ 津 行, 極 銀 参学大 二 を機学に、銀と化行照を古五

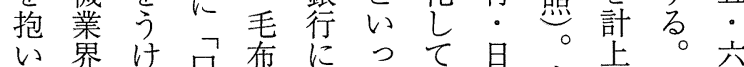
たのた座。取たい本当しし年 で不者を敷り産た興該は少頃 あ振㤎開布付地た業期す似 ろは多関けのめ銀にる、降

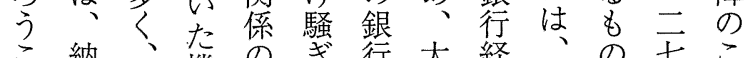
こ納、機機き行大経泉の年亡 は谷近屋機業起倒分江 部背の、にで 想織銀加家こ産の大機期はあ 像物行な加を機蔵業梨金り に品の対同泉業省地利融、 難 場 休 の象銀北家預全潤恐表 くの業数に行機は金体は慌 2 な経・数金は業全部の対肪に い営破に融倒にく資景前あ見 。に縃上活産打窮金気期りる ま対は上動し撃状の金比、

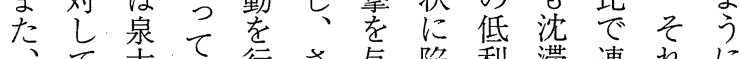
こも津拉行さ方陷利滞連机に の 等 時し機っい翌的学お期くも 期く業預た立すた受りに昭年 の打界金同七なと和上

製融て

品上 の 販 取 点 売引が 先は特 に見徴 ᄂ 5 な 、なつ 原いて 系。い の 。 購 先 ま に 取

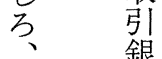

取行 引 銀地 に の ᄂ 和 万、泉 
第26巻 第 4 号

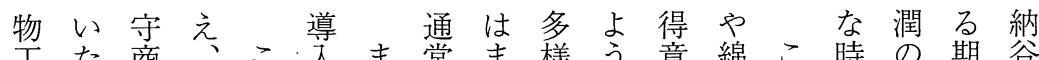

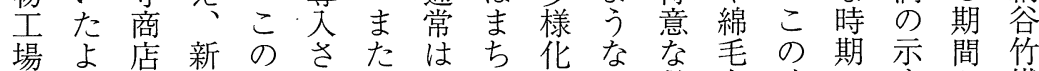
場よ 店新 の らで大く期てこ五いと綿布等期 あ 数 あ物 はあ阪、の生の\%なっ織にをにつ值り工工 綿り市江製産時前い借物加生はたよ、場 毛、西守品力期後。入文文産、とりそは、

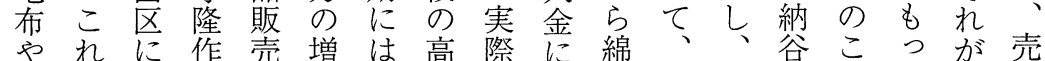
混古商先強、水、依織新徐竹と妻掛 綿らつ店はも従準資存物た々松で切業金 毛後た、製図来に本しとににはあ実資が

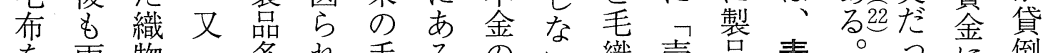
を両物二多れ手るのい織売品表。つに倒 買者問 商様て 織判納物れを い, の 屋店化い機表明谷と筋多にとわに 入取 にるに 2 す竹の商様見のれな

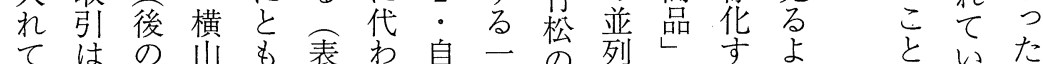

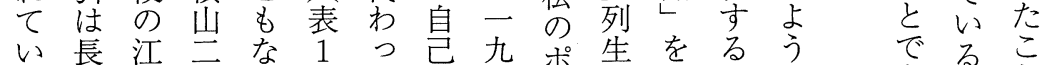

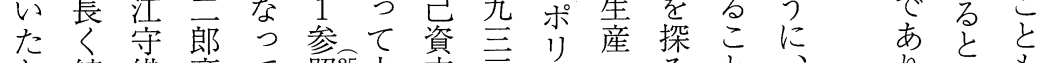

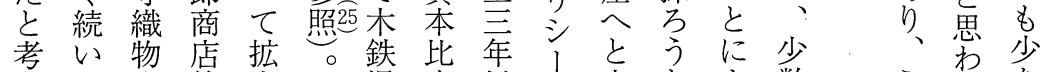

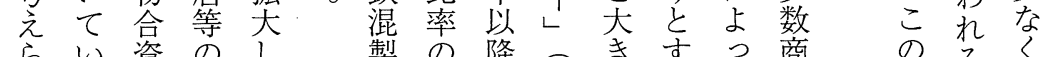

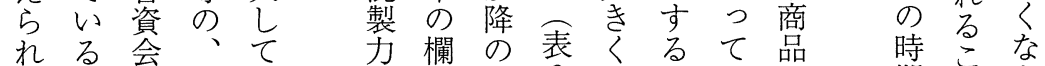
る。社大い織参自 2 製、期と加

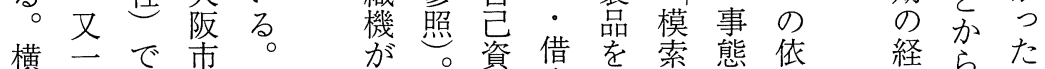
山商、内守使本入多期の存 商店納のな用比金様打体 店は谷織わ芑率の化之開質 は大竹物ちれ れ欄さ位をを 泉阪, 織問、、参也置図改 北市物屋前々最照たづろめ

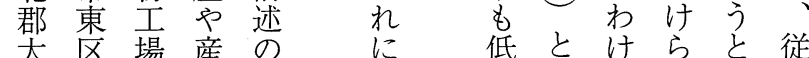
津に少地道々 いがでれし来

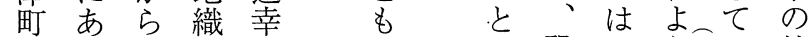
所つは物 な恐なう望い紋 在た主仲園っで慌がるる敷 の織に買部てて も期つこ。布 産物紋 が 地闇 嶅 登 布 場 野 電 物でを导しの車 仲、買て 各 買納いw商 で谷入る店電 竹れ。に 紋 織て 江 加 が

南 八公た れす 海 二経がはな卓 電 一営、等 車 示索 等 後 文支の是当加 あた製ら当該え が $\begin{array}{lllll}\text { あた 製 ら } & \text { 該 } & \text { え } \\ \text { り } & \text { 品 } & \text { 期 } & \text { 肩 } \\ \text { と } & \text { の } & \text { は } & \text { 掛 }\end{array}$

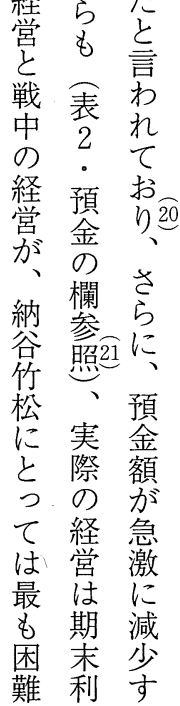


経営史 学

や絨泉川に店そのい場入当も園よ敷

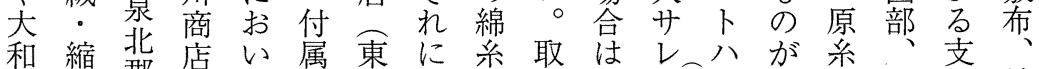

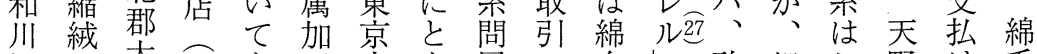
河・津泉あ工市も屋の系し殆経こ野は毛 畔染津北るは泉な气問の系の の あ布 の色町郡 程第駄つ移工屋がドに時各ま等 磯等に大度二皇て 行イで一 皆は期商りを 原に関対津 整 期 谷部し 分 た 織ししさ兄りで的も文岩と言了綿これ入 にててがれさあにのき田言フ一系のなれ よもな晒てらり紡とい惣わべ六が時いて る、さ白きに、績考の至れク番大期。い そ大れ加た地毛会えは郎て、手半に受た れ津て兄こ元系社ら岩商い総のでは取よ

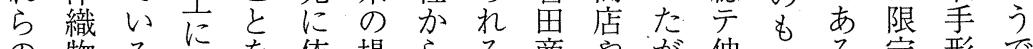
の物る応を依場らる商やが仲のる定形で 加任。意存合の佔竹、買が○さにあ

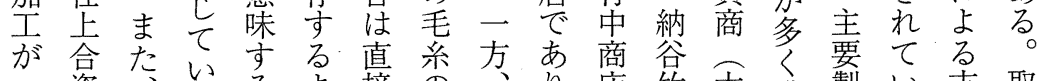

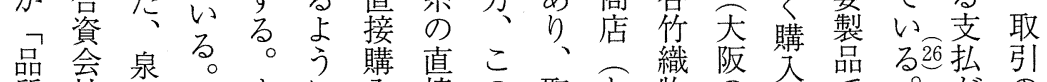

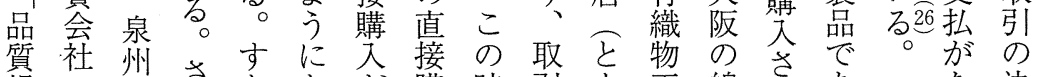

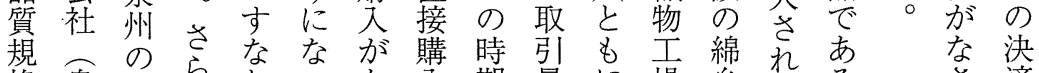
格泉最らわっな入期量に場系てれる。決

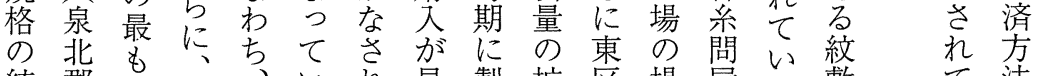
統郡得紋、いれ見製拡区場屋る敷佉

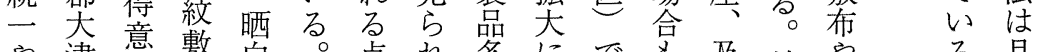
や津意敷白。点れ多にでも及綿や

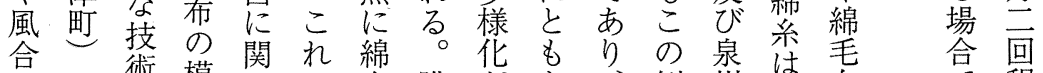
いが術模し成筽購がな、例州は、布 泉程 のそと様て、取入あう地にの戦は 独れ言をは付引先る織は元漏綿前厚、

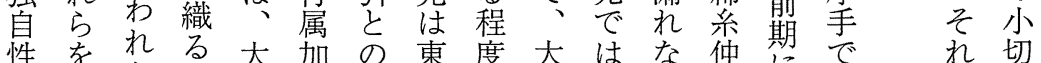
性をれる大加の東度大はな仲に期で切 を担たた起阪相京進口前い買はああ

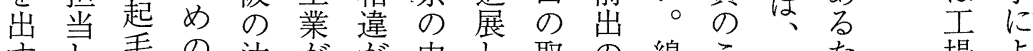

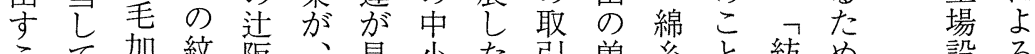

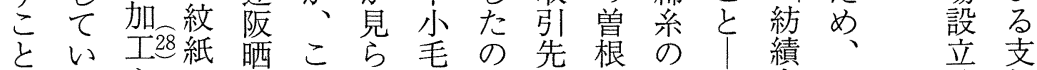
がるやの西の和系はは勝購筆会特時払 必。比発場 時る 紡 既、商入者社に ず従較注以期。績述地店先註寻緯的主 し来的が外にでの元かは积で

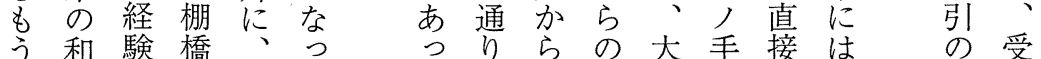
ま歌の紋地てたで大購阪 く山浅紙元、吉あ阪入市経入番公 行毛い土泉田る市加内示儿手道形 か 織 洗場小北商が内多の購、、の幸に 
第26巻 第 4 号

毛綿納沗量来てい第以至竹伀な述元た 卆 毛谷泉は拡りた製期上まの引い心四こ後

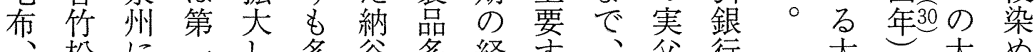

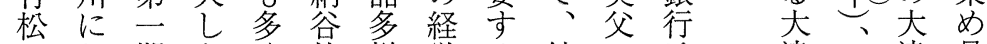
綿に扔期たく竹様営る納。は津一津品 毛とけなたの織化とに谷久学公織に 混っるりめ織物はは竹吉従製九物つ 織て付 8 、物工、多第織㤎来䋐 $\overrightarrow{0}$ 仕 肩第属地大問場後く二物理 の 株年

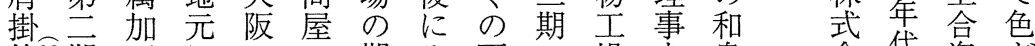
等33期工にの期 み面分場を泉会帒資が のは体依い産年らで納の務銀社後会揃

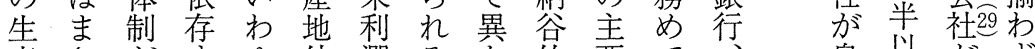
産さが文仲潤るな竹要て里泉降がず

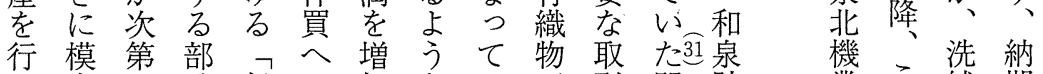
い索に分船の加ない志引関貯篻こ䋐期 、の整が場製に綿た場銀係蓄ににの和 次時備多以喿転織。の行も銀扮会縮守 第でさくのの換物す経のあ行 にあれな綿販せ少な営—つに 毛つつつ系売しらわはつて妿

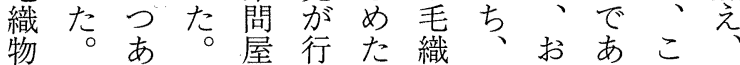
生紋っそかわ。物紋りりれ大 産敷たれられまへ敷か続以津 肪布こは直たたの布ら䦿降信

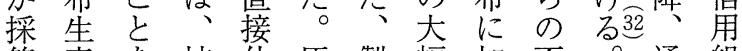
算産を技任原製幅加不。通組 のを意術入系品なえ況常合 採中味的れ購多製てを市 犯心守にる入稼品綿脱当属 事据。熟場は化転毛出座州 業宾㤎系製で售金行

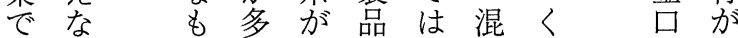
あがのか中販な毛採座登 るらをつ心売か綿用のの場 こも大だ先つ毛さ開䙳 と、阪。あのた布机設る を利市付っ多も、たは

実益内属た様の肩製も大

感率や加が化の掛品占津

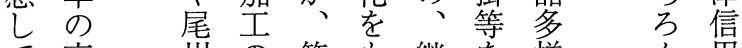

て高州の第を継を様角

いいに内 $一$ も続も化資組

く綿依い期た的生に金合

の毛存く占らに産よ者

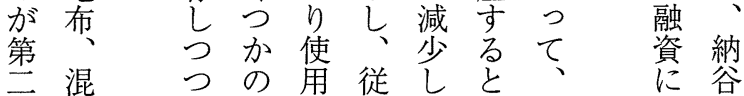

け社絨 ら

るが、れ

仕、染ず 上泉色手 加北? 違 工 の 乾 い 業 仕 絨 が の上 等 続 整妿のい 備仝設た に果大備よ たき増め しな強 た部 L一 役分本九 割を格— は担的七 非うな 年 常よ整に にう理深 大に仕井 きな上伊 $\leqslant \circlearrowright$ 架 辛 評吉 体に 価こ制よ さのをつ 机会整て ね社芝設 ばやこ立 に谷な後二 
経営史学

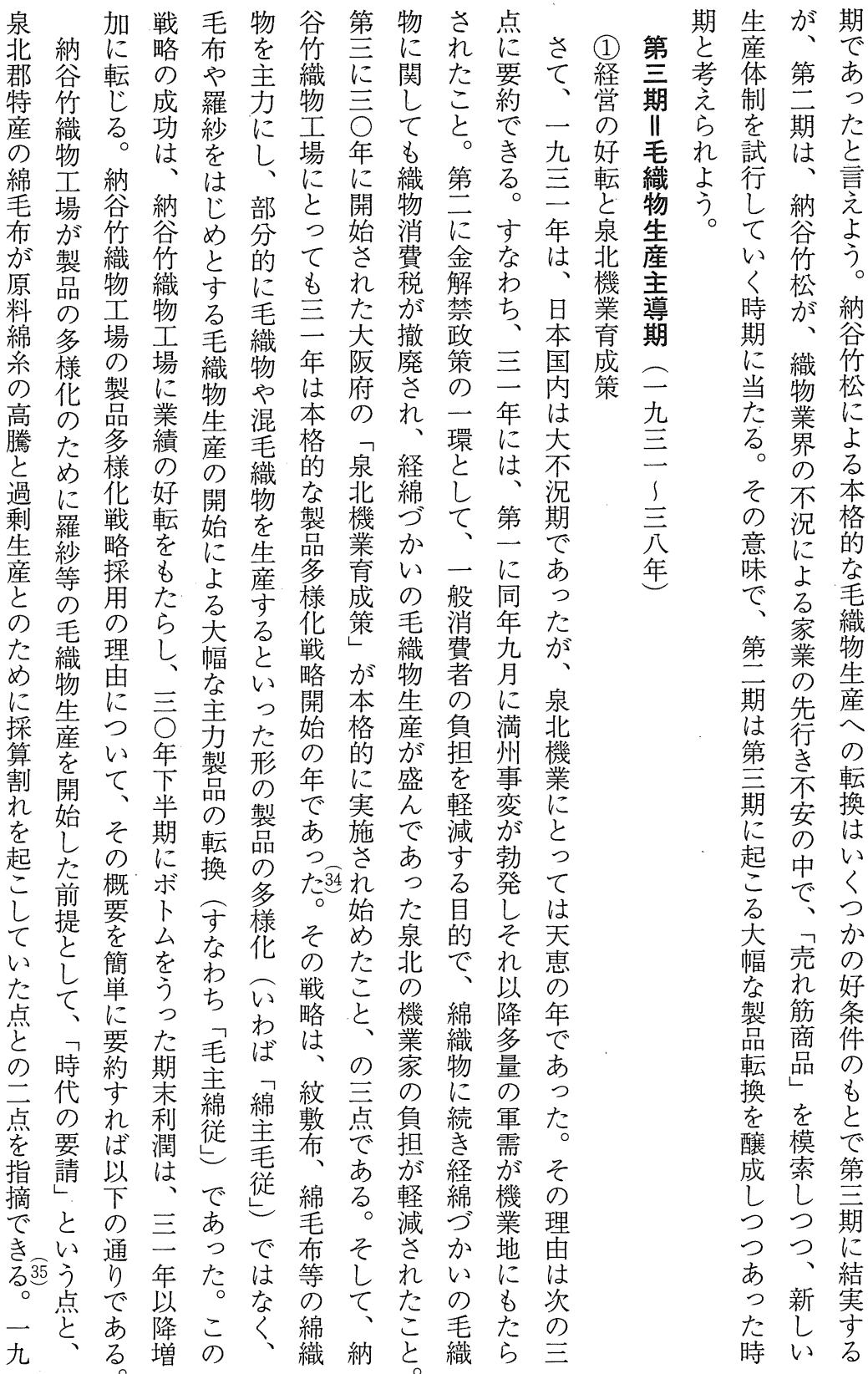


に思製閑 ら府府綿め対たる毛ス特三

組は織散すな立知し織るすすこと布りに可 み前を期ない情杢事加物よると方生ン毛年 合任指とわ。業: わ出う対を礼産や織代 わ地導のち奨柴こらに応付ばの着物の せ䖞美差励田れ毛な策け、拡尺贡旦 る愛るを一館善ら織つを加生大 セ業本 己知よ改九茥の物た模艺活のルの羊 とでう善至び郎点へ。索る様最の分毛 にあにし 同のはのししこ式大よ野工 より依機泉い製たてとののうで業 つ、頼業昭 津北わ品がいが近原な最は

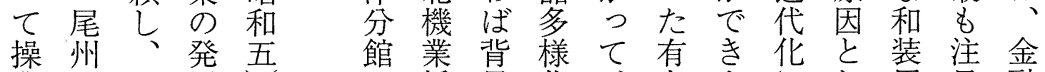

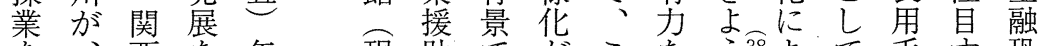

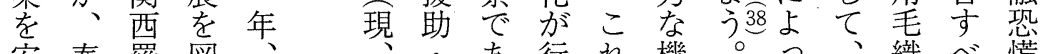
安春羅図、泉市行れ機。つ織べ慌 定夏紗る 泉 逳有る。 せの協くをを府策むた要は羅洋事生向解 て 会、視立にしと因、紗装変産は、禁 い秋の関察緎呼乃言を一・索以が、後 た冬代西し維応、少九背九、降激羅の 事も表羅た技し納よ景三布男の減紗不 実のと紗大術た谷う方 かの泉商阪 研関竹。し

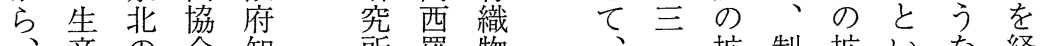
、産の会知所羅物搪制拡小な 経 こを毛会事紗工泉年大服大う洋た れ、布長。商場北にはと悲服後 をあ製・柴占協が泉泉い確用 泉る織梅田 る会毛納羅北ううな毛一 北い業村善羅に織谷紗に形た コ織九 には者衡豆紗よ物 竹等も无こン物 三 お洋の平郎製る羅狌織 の

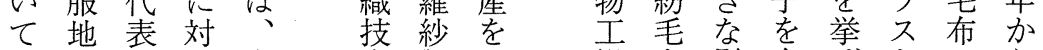
もととし泉術製開場を影含げトのらら

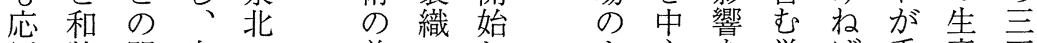
用装間泉の 普のし心学ば看産五 し用の北毛是指た方与生なて が年 泉着意の布 努 導直 な方層ら取急頃 北尺見毛生方亡接有る机増に

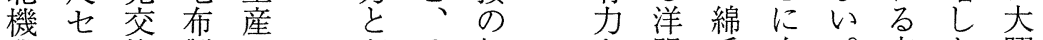
業儿換製に㤎そ契な服毛次。点た 躍 ののを織お強れ機織地布第さざ゙の進 安生斡業け調にと物へのにらあに期

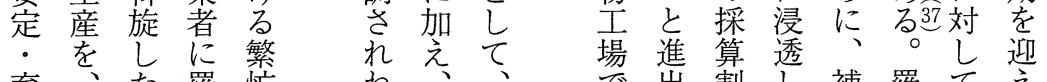

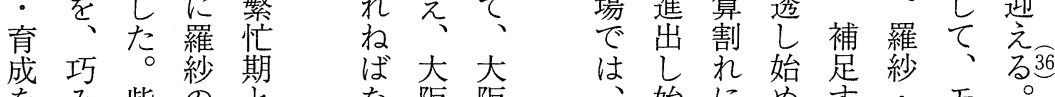

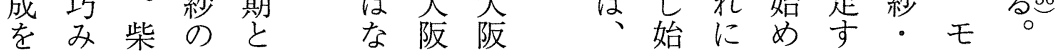


経 営 史 学

採の三れ輸き竹を頃こ技羅泉一紗丸図 算減二、出さで織開以と術紗州方の紅 状収年ま再てあ物始降がのを機試商う 況状にた禁、万王し、開は業大し店と に態羅、歨毛う場た泉っ発じ地阪織㤎し 有を紗為と織。の年州たをめの府り泉た 利打生替々物毛とにた行と指立用州

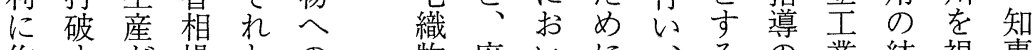
作守崲 と事物府いに、るの業紡視事

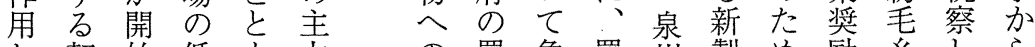

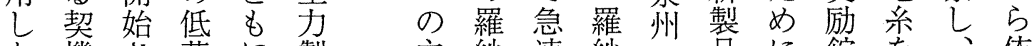
た機さ落に製主紗速紗の品に館を、依 こと扚開品方奨に製機の、支第頼 は なるもも始の転励羅織業企大本給にを受 否たでけれ換のがの警を設府管心゙泉け めとはらたに転活生戒指計立のき州た な考七れ積よ換発産さ導を織事の関

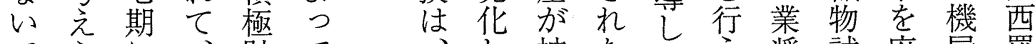
でらに、財て、し拡たたう奨試府屋羅 あれわ泉政、府た大长励験にに紗 万るた北の納に年卞羅方館部答尾商

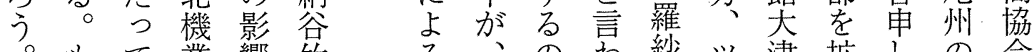
○もて業響竹る、の紗ツ津拡し の会 しち減は早織羅とでれはイ分充た毛艻 から収再、物紗も市て危１館し。織ら

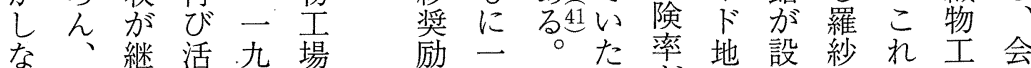
がこ続気吴の策九以ががの置製を場長 られしら経に主、大新さ織受をの

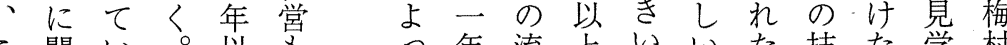
こ関い。以も年流上いいた技た学村 のした 既降安てでれの割仕。術府さを 減ての述は定もあかよに声こ指はせは 収はでの多の大っらう利げの導、、、し 状、あょ額方きたすな潤技大考第め

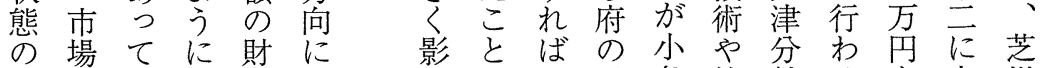
打条、政向響は奨さ梳館せを大

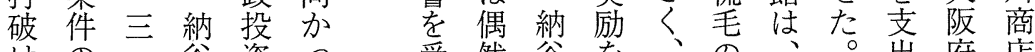
はの三谷資つ受然谷老、の背

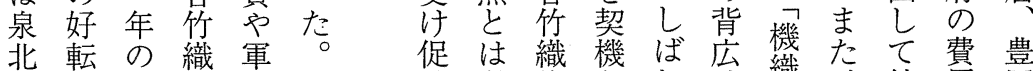
の俥羅物事—進考物とし地織紡角畐 機納紗工費九热兄しばのり 指で商 業谷生場等学机場て損染導九系泉店

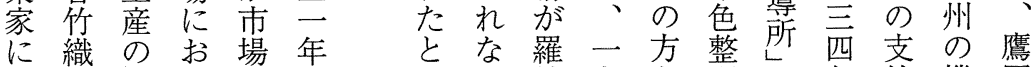
共物開いに年考い紗九环々年給機岡 通工始て投末元。の方等とに热商

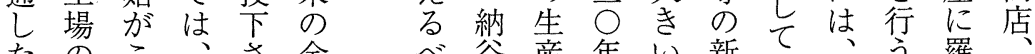
た氙さ金签産年い新て、、羅 


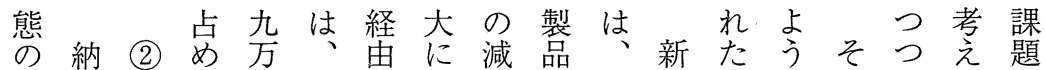

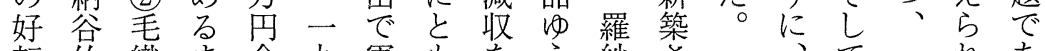

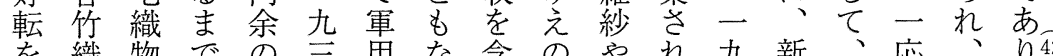

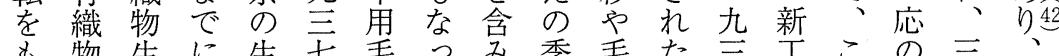

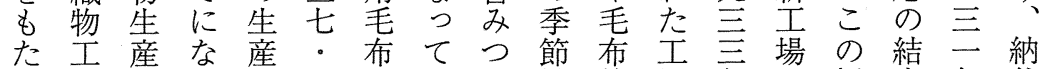

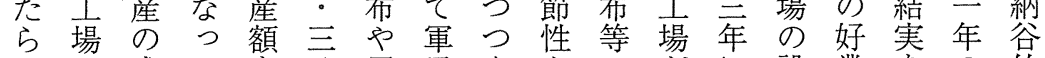
しの 成てを軍需も录の加に設業をの竹 た製功い誇年用を全ら毛稼開備績見羅松 要品にる新り頃帽中体か織働始にをた紗も 因多よ。它、下物し光は背結生減 は様るま全戦地にし半生始れ、景果産収 何化工た生前の毛て期産めた従にとのの た戦場、産期買織非にを、新来、見開恒 つ略経期額の以物常は拡従築の納る始常 たは営末本最上需に若大来圭谷べと化 の、の 利三盛げ要急芉すの事鉄 竹き期を か 既好潤主期 がが速のる綿は混松で、末何 を述転も・実拡で業こ織晋製はあ利と

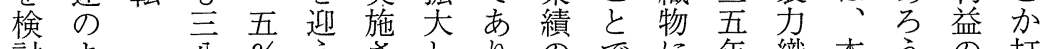
討よ 八 $\%$ えささしりのでに年織本うのの打 し.う年をるれる、低好加に機格。好破 上に占。た数好卡転え完一的転卞

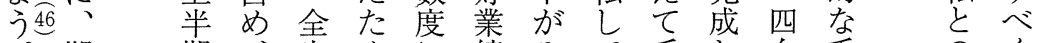
そ期 期、羅産め、少績み の利降紗額泉た窺れつ物納加物致折

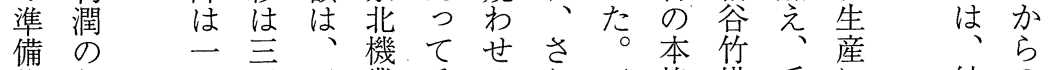

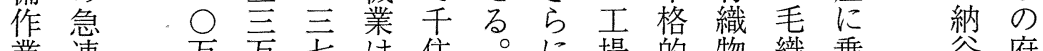
業速万方七は住。に場的物織乗谷府 とな円円年二製特は新な 工物り し増の余に気䋐に室築生場生出松奨 て加大のはに所、彦以産は産すす励

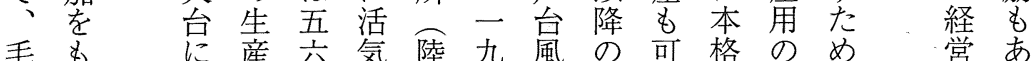

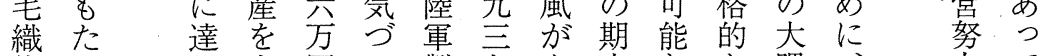

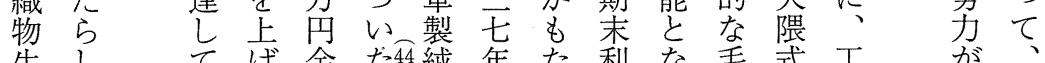
生し て げ、余 た。出䋐 年た 利 な 毛式 工 が。 全上そ秒

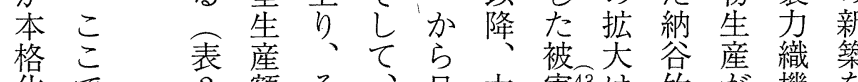
化で $\quad 2$ 額そ 、日大害出は竹孞機を しは参のの納本陸な、織可が行 て 照五う谷毛でど毛物能三う いこ たの・毛織 工 戦よ物場な 台 既

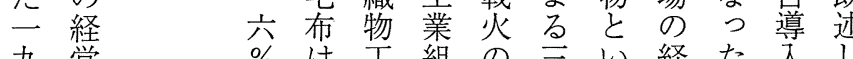
九営奖 況生 の 産 好を 転 開 に 始 \& L 助 た け らの れと 
経 営史 学

にれき関はく紡前先に紡業事じ化 例た表 $\quad F$ る し、凌の半ずす 便し と \& 5 固と ず浮か て同駕業の総る宜てしのは定に、きら 、年し 績 水資。でいてで、資す 総彫 三

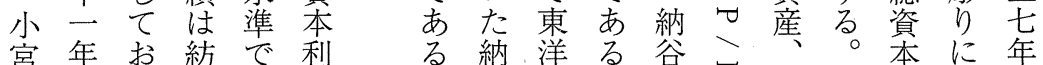
丵間り績推益 た谷紡。竹

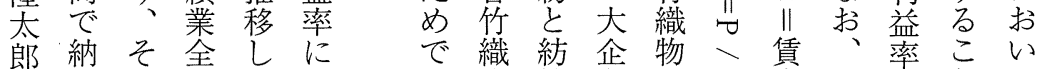

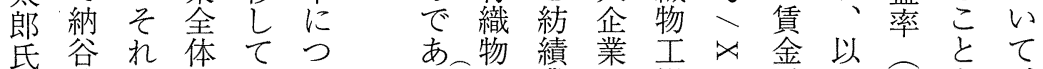
氐谷れ

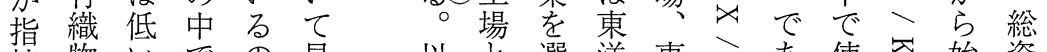
摘物いでの見 以市選洋東市使さ始資

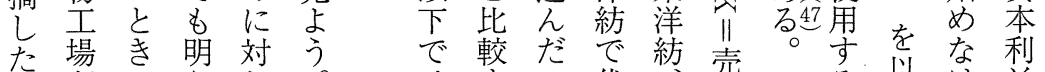

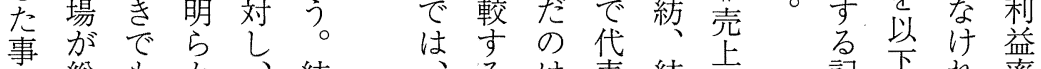
実総も加、紡文紡高記下表京

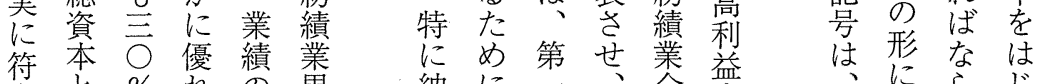

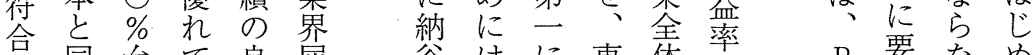
呈同台て良屈谷はに東众率 $\mathrm{P}$ 要な

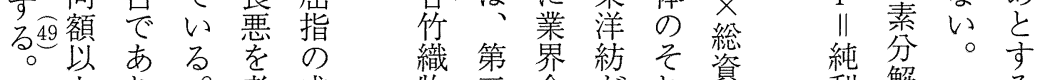

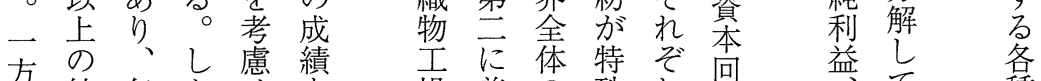

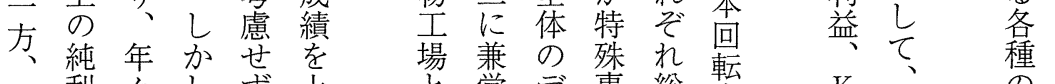

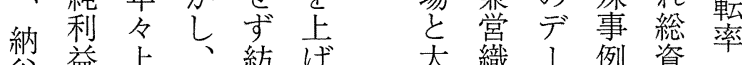

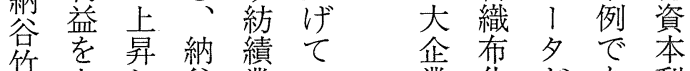
竹上し谷業い業化があ利 織げつ竹全た の品最る益 物たつ織体東代進毛場率 場こ二物で洋表み得合を のと九王み紡皇少や売 売を至場たの

党 意 は総 緿

上䯩味年そ資資

高利にの本采 益。は東利利

率こ二洋 益 益

もれ○のはが

凶は％総六光比率績併本

は戰超本八該利 \% 期 て

紡のて益でに見てり載と 績中い率あはてい、行い 業小るをり 支 行た織て 積 全企。も東布あ元 体業こ大東 $\%$ こ洋専る。表

$\mathrm{K}$ の

II 他経

総の営

資指指

本 標標

、の の

$\mathrm{X}$ 変推

II 化移

売㤂劣

て 高 い 慮 高

のい繊 L 利

東 総 維 て 益

洋資 産 紡 率

紡本 業 績 と

高益利険

$\begin{array}{lll}V & \text { W } \\ \text { II }\end{array}$

付 心谷

加に 竹

価影織

值 響物

L る 場

\|かの

従を経

業分棠

員析安䒠 
要素分解による比較 $(\mathrm{P} / \mathrm{K}=\mathrm{P} / \mathrm{X} \cdot \mathrm{X} / \mathrm{K})$

\begin{tabular}{c|c|c|c|c|c|c|c}
\hline \multicolumn{2}{|c|}{$\mathrm{P} / \mathrm{X}:$ 売上高利益率 } & \multicolumn{4}{|c}{$\mathrm{X} / \mathrm{K}$ : 総資本回転率 } \\
\hline 納谷竹 & 東洋紡 & 紡績業 & 年 次 & 納谷竹 & 東洋紡 & 紡績業 \\
\hline 0.267 & 0.405 & 0.100 & 1933 年上期 & 1.381 & 0.273 & 0.725 \\
0.572 & 0.403 & 0.090 & 1933 年下期 & 0.735 & 0.282 & 0.806 \\
0.353 & 0.448 & 0.101 & 1934年上期 & 0.968 & 0.315 & 0.828 \\
0.353 & 0.399 & 0.091 & 1934 年下期 & 0.968 & 0.330 & 0.893 \\
0.267 & 0.357 & 0.087 & 1935 年上期 & 1.544 & 0.366 & 0.894 \\
0.419 & 0.382 & 0.087 & 1935 年下期 & 1.088 & 0.342 & 0.855 \\
0.253 & 0.390 & 0.086 & 1936 年上期 & 2.791 & 0.329 & 0.784 \\
0.384 & 0.383 & 0.083 & 1936 年下期 & 1.774 & 0.328 & 0.790 \\
0.258 & 0.378 & 0.088 & 1937 年上期 & 2.868 & 0.360 & 0.849 \\
0.314 & 0.364 & 0.087 & 1937 年下期 & 1.683 & 0.377 & 0.805 \\
0.558 & 0.341 & 0.089 & 1938 年上期 & 1.844 & 0.441 & 0.757 \\
0.468 & 0.308 & 0.093 & 1938 年下期 & 2.669 & 0.448 & 0.706 \\
\hline
\end{tabular}

上

回

工場決算簿』，『昭和 7 年起納谷竹織物工場決算簿』、『昭和 12 年納谷竹織物工場売原簿』,『昭 納谷竹織物工場原簿』, 『納谷竹織物工場新築控』, 貢金に関しては, 谷口行男『泉南郡綿織物 参照。

東

洋

紡

それ以外の女工賃金は1937年を 100 とした日銀卸売物価指数を乗じて算出した。また, 『日 率を算出した上で, 男工賃金は女工賃金の1.8倍とした。

した。それ以外は 35 年下期から 40 年上期まで, 半期ごとの増加率を 1.102799 と仮定して 40 年

986年) 所収統計，三菱経済研究所『各年版本邦事業成績分析』、『現代日本産業発達史11 瀻 を参照。

年版綿系紡績事情参考書』, 三菱経済研究所『各年版本邦事業成績分析』, 関桂三『日本綿業論』 と化㵶の産業構造 別冊・綿と化緎の基本統計表』(1956年)を参照。 史11 瀻維(上)』(1964年) を参照。

計表』を参照。

100 とした日銀卸売物価指数を $34 \sim 36$ 年の賃金の 3 ヶ年平均に乗じて算出した。

の

そ

れ

l一

比

ベ

$\tau$

全

般

的

に

w

う

低

位

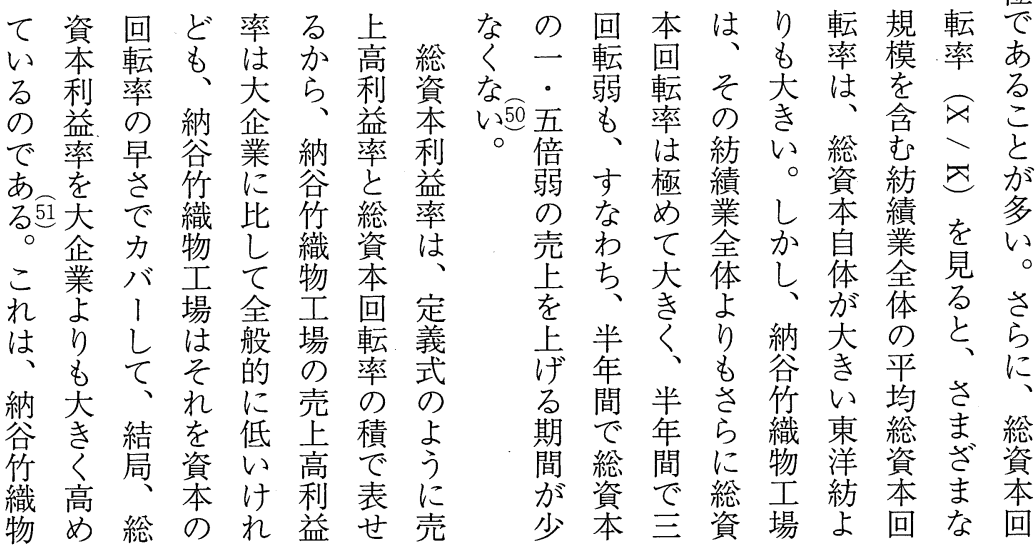


経 営 史 学

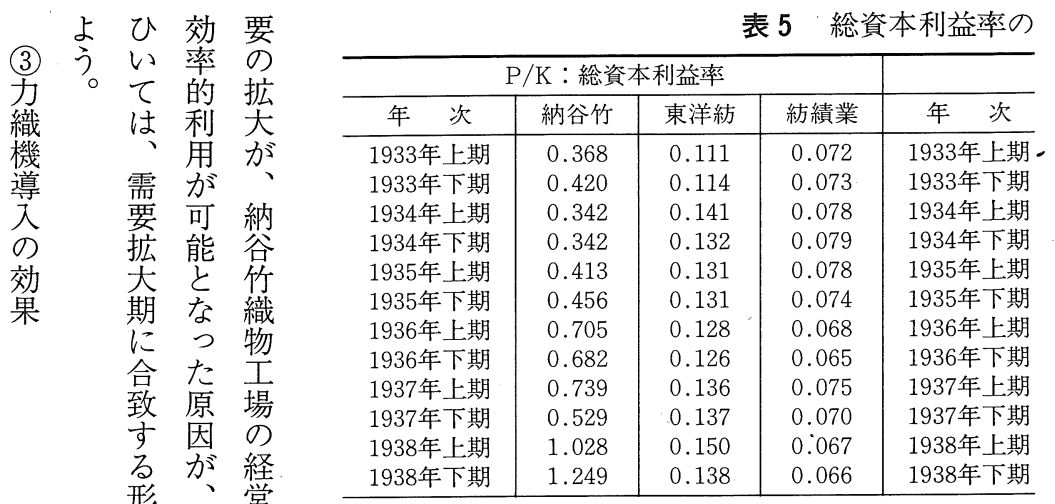

【納谷竹織物工場】

資料：『大正13年起納谷竹織物工場決算簿』，『昭和 2 年起納谷竹織物 和13年納谷竹織物工場売原簿』，固定資本に関しては『昭和15年 発達史』(1950年) 135頁, 『日本綿業統計』, 『工業統計書』を

注 1 : 年間操業日数 $=330$ 日, ゆえに半年間操業日数 $=165$ 日とした。

$2 ：$ 職工賃金は1937年の女工賃金が資料から判明したので依拠した。 本綿業統計』及び『工業統計書』によって男工：女工の賃金比

3 : 固定資産は $1933 ， 34 ， 35 及 ひ ゙ 40$ 年が資料から判明したので依拠 上期に資料の数值通りになるように推計した。

【東洋紡績】

資料『東洋紡績七十年史』（1953年）付属統計，『百年史 東洋紡』（1 維(上)』(1964年) 付属統計表, 『日本綿業統計』, 『営業報告書』

注：支払貢金は製造費の8\%であるとした。

【紡績業】

資料：使用総資本，固定資本，流動資本，売上，支払に関しては『各 （東京大学出版会，1954年）付属統計表，三菱経済研究所『綿 男工数, 女工数, 職工数合計に関しては, 『現代日本産業発達

賃金の額に関しては，日本紡績協会『日本綿業統計』，『工業統 注 $1 ： 1938$ 年の賃金が不明であったので，1934〜36年の三ヶ年平均を 2 : 付加価値の算出は加算法に拠った。

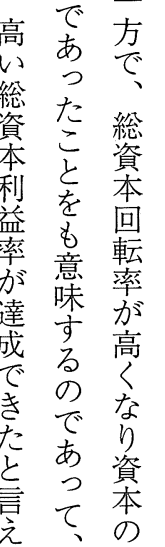

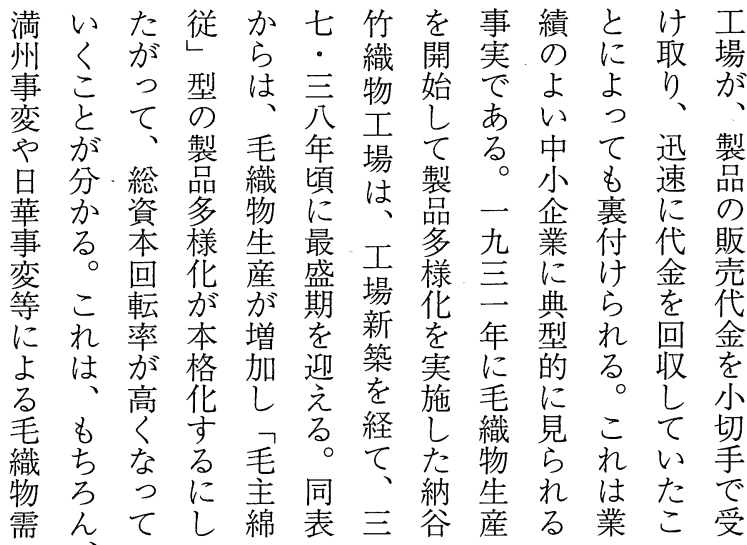


第26巻 第 4 号

表 6 納谷竹織物工場における総資本利益率 $(\mathrm{P} / \mathrm{K})$ の対前期比と 諸変数の対前期比との回帰分析 (被説明変数 $=$ 総資本利益率)

\begin{tabular}{|c|c|c|c|c|c|}
\hline 説明変数 & 回帰式 （）内は $\mathrm{t}$ 值 & 決定係数 & 標準偏差 & DW & $\mathrm{F}$ 值 \\
\hline $\begin{array}{c}\text { 総 資 本 } \\
\text { 投資効率 } \\
\mathrm{V} / \mathrm{K}\end{array}$ & $\begin{array}{l}-0.07607+1.07762 \cdot r(\mathrm{~V} / \mathrm{K}) \\
(-0.13753) \\
(23.05595)^{* * *}\end{array}$ & 0.983351 & 0.0463 & $2.011^{!}$ & $531.577^{* * *}$ \\
\hline $\begin{array}{c}\text { 総資本 } \\
\text { 回転率 } \\
\mathrm{X} / \mathrm{K}\end{array}$ & $\begin{array}{l}0.88177+0.23200 \cdot \mathrm{r}(\mathrm{X} / \mathrm{K}) \\
(3.92855)^{* * *}(1.36903)\end{array}$ & 0.172356 & 0.3261 & $2.375^{!}$ & 1.874 \\
\hline $\begin{array}{c}\text { 利 潤 } \\
\text { 分配率 } \\
\mathrm{P} / \mathrm{V}\end{array}$ & $\begin{array}{l}-21.1922+22.2319 \cdot \mathrm{r}(\mathrm{P} / \mathrm{V}) \\
(-9.0723)^{* * *}(9.569)^{* * *}\end{array}$ & 0.910560 & 0.1072 & $1.127^{?}$ & $91.565^{* * *}$ \\
\hline $\begin{array}{c}\text { 付 加 } \\
\text { 価值率 } \\
\mathrm{V} / \mathrm{X}\end{array}$ & $\begin{array}{l}1.03853+0.10409 \cdot r(V / X) \\
(3.83966)\end{array}$ & 0.025326 & 0.3539 & $2.581 !$ & 0.231 \\
\hline $\begin{array}{c}\text { 付加価值 } \\
\text { 生 産 性 } \\
\mathrm{V} / \mathrm{L}\end{array}$ & $\begin{array}{l}-0.06432+1.06491 \cdot r(\mathrm{~V} / \mathrm{L}) \\
(-12.865)^{* * * *}(252.939)^{* * *}\end{array}$ & 0.999859 & 0.0043 & $2.093^{!}$ & $63977.5^{* * *}$ \\
\hline $\begin{array}{c}\text { 学 働 } \\
\text { 装備率 } \\
\mathrm{F} / \mathrm{L}\end{array}$ & $\begin{array}{l}0.45510 \\
(0.32136)\end{array}+0.64486 \cdot r(\mathrm{~F} / \mathrm{L})$ & 0.026791 & 0.3536 & $2.538 !$ & 0.248 \\
\hline \begin{tabular}{c} 
設備投資 \\
効 \\
\multicolumn{1}{c}{ 率 } \\
$\mathrm{V} / \mathrm{F}$
\end{tabular} & $\begin{array}{l}0.38430+0.73950 \cdot r(\mathrm{~V} / \mathrm{F}) \\
(1.04339)(2.16279)^{* *}\end{array}$ & 0.341993 & 0.2906 & $2.848^{!}$ & $4.678^{* *}$ \\
\hline $\begin{array}{c}\text { 売上高 } \\
\text { 利益率 } \\
\mathrm{P} / \mathrm{X}\end{array}$ & $\begin{array}{l}1.01311+0.12541 \cdot \mathrm{r}(\mathrm{P} / \mathrm{X}) \\
(3.81014)^{* * *}(0.59416)\end{array}$ & 0.037744 & 0.3516 & $2.591 !$ & 0.353 \\
\hline
\end{tabular}

注 1： $\mathrm{t}$ 值及び $\mathrm{F}$ 值の右肩に付いた * は $10 \%$ 水準, **は $5 \%$ 水準, ***は $1 \%$ 水準で有意であるこ とを示す。計算方法は, OLSもしくはGLSによっている。

2：DWはダービン・ワトソン比である。OLSでの計算結果に関して明らかに誤差項に自己相関が ある場合は，GLSによってそれを回避している。各数值の右肩についている！および?に関して は，！は誤差項に自己相関なし，？は誤差項に自己相関があるかどうかは不明，を意味する。

3 : 計算には各数值の対前期比を用いた。

$$
\begin{aligned}
\mathrm{P} / \mathrm{K}=\mathrm{P} / \mathrm{X} \cdot \mathrm{X} / \mathrm{K} \\
=\mathrm{V} / \mathrm{K} \cdot \mathrm{P} / \mathrm{V} \\
=\mathrm{X} / \mathrm{K} \cdot \mathrm{V} / \mathrm{X} \cdot \mathrm{P} / \mathrm{V} \\
=\mathrm{L} / \mathrm{K}^{*} \cdot \mathrm{V} / \mathrm{L} \cdot \mathrm{P} / \mathrm{V} \\
\quad=\mathrm{L} / \mathrm{K}^{*} \cdot \mathrm{F} / \mathrm{L} \cdot \mathrm{V} / \mathrm{F} \cdot \mathrm{P} / \mathrm{V}
\end{aligned}
$$

〔上の定義式において,*のついている指標はその逆数が定義式の中にビルト・インきれている。した がって，その指標は総資本利益率に反比例する。】

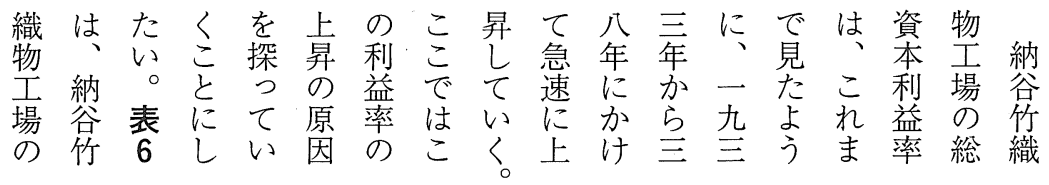


経 営 史 学

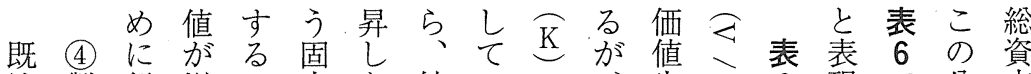
述製行増の定た納いに、生文 6 現で分本 の品っえで資結欲る比納産こにしは析利 よ販た、あ本果竹こ比谷性のよた。に益 う売声さりの織と竹の上れ。分よ率 に先場ら、増設物を辇上昇ば析つの

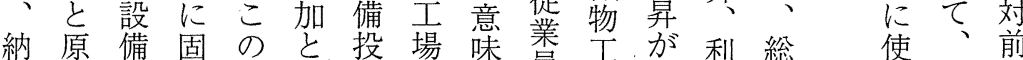
谷系の定新は資の卞員場与潤資角当期

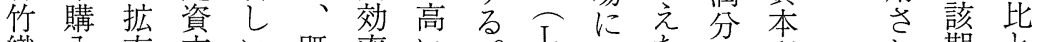
織入充本い既率い。 物先がが生述文付付がい影率益 工、拡産の学加加相て響率

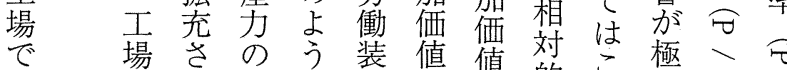

は経れ拡に備生生的こ植ら

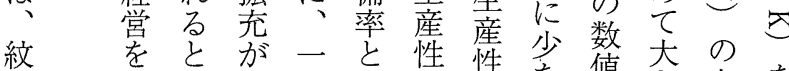

敷

等

の

綿

織

物

の

製

織

行

わ

れ

r

た

离

製

の

進

展

k

६

な

?

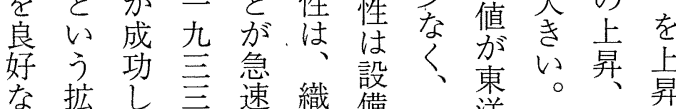

な拡し亥速織設、苯。洋—設さ

し循こ以高な機资方紡般備せ

め環と降まど資でや船投た

たがににっの起策相紡に资箐要

言起よ塞た有率效縉中率は

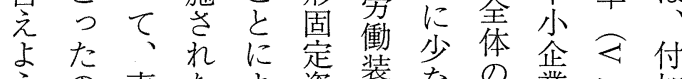

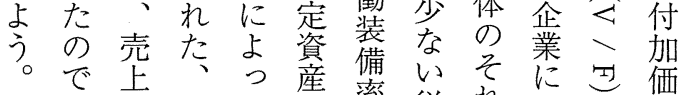

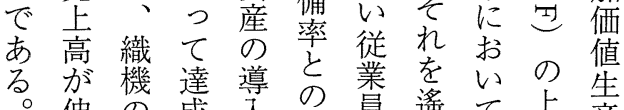

○伸の成入積員遥て昇産

ま、新尜成宾極に付算性

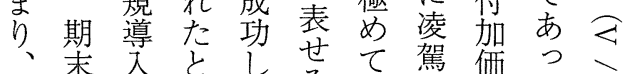

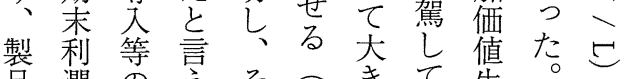

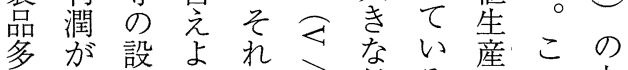

様増備うにう付る性の上暴

化加の。少加。は中暴

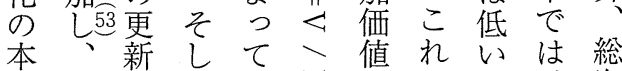

格そ新宁生利はの资

的 $\mathrm{L}$ 拡、産宁 $\widehat{\mathrm{V}}$ 名

塞て充こ性さ総通に投

施付をこ㤎さを資烈付資

た加意で急心䅉本で付效
れ期

たに他

数はの

值、経

が ど営

対 9 指

前経標

期嫦 $の$

比標前

あの期

あ増比

る 加 と

とがの

を総

示資で

す本回

め益分

例 学

堌実

総最々

資寄 穴

利与結

益た卒

の の -

対架覧

前星に

期 5 L

紫た

ずて の

文る挃あ 
表 7 納谷竹織物工場における製品販売先一覽(1937年)：上位のもののみ

\begin{tabular}{|c|c|c|c|c|}
\hline & 販売先商店名 & 所 在 地 & \begin{tabular}{|c|} 
取引金額：円 \\
$〔 〕:$ 比率
\end{tabular} & 備 \\
\hline 羅 & $\begin{array}{r}\text { 芝川商店内地部 } \\
\text { 輸出部 }\end{array}$ & $\begin{array}{l}\text { 大阪市東区高麗橋 } \\
3\end{array}$ & $\begin{array}{c}151,485 \\
\lceil 26.6\rceil \\
50,698 \\
\lceil 8.9 〕\end{array}$ & $\begin{array}{c}\text { オーバー地が大半。決済は月 } 2 \text { 回 } \\
\text { (15日と月末) 小切手で行われる。 }\end{array}$ \\
\hline \multirow[t]{2}{*}{ 紗 } & 藤野房吉商店 & $\begin{array}{l}\text { 大阪市東区伏見町 } \\
5\end{array}$ & $\begin{array}{l}89,889 \\
\lceil 15.8 〕\end{array}$ & $\begin{array}{l}\text { オーバー地, 経綿ピッケ。小切手 } \\
\text { による決済。3\%の值引き有り。 }\end{array}$ \\
\hline & 吉沢商店 & 大阪市東区 & $\begin{array}{l}15,678 \\
\lceil 2.8\rceil\end{array}$ & $\begin{array}{l}\text { 薄メルトン地。小切手による決済。 } \\
3 \% \text { 值引き有り。 }\end{array}$ \\
\hline \multirow{2}{*}{$\begin{array}{l}\text { 毛 } \\
\text { 布 }\end{array}$} & $\begin{array}{l}\text { 日本毛布工業組 } \\
\text { 合 }\end{array}$ & 泉北郡大津町 & $\begin{array}{l}170,739 \\
\lceil 29.9 〕\end{array}$ & $\begin{array}{l}\text { 軍用毛布 } 17,177 \text { 枚, 軍用帽子地 } 37 \\
\text { 反。 }\end{array}$ \\
\hline & 又一商店 & $\begin{array}{l}\text { 大阪市東区南久太 } \\
\text { 郎町 } 2\end{array}$ & $\begin{array}{l}22,037 \\
\lceil 3.9 〕\end{array}$ & 毛布 3,300 枚他。小切手による決済。 \\
\hline \multirow{3}{*}{$\begin{array}{l}\text { 紋 } \\
\text { 整 } \\
\text { 等 }\end{array}$} & 道幸久治郎商店 & 泉南郡佐野町 & $\begin{array}{r}36,873 \\
{[6.5]}\end{array}$ & $\begin{array}{l}\text { 紋敷布が18,807枚他。小切手によ } \\
\text { る決済。1.5\%の值引き有り。， }\end{array}$ \\
\hline & 横山二郎商店 & 泉州 & $\begin{array}{l}9,520 \\
\lceil 2.8 〕 \\
\end{array}$ & $\begin{array}{l}\text { 紋敷布が6,780枚。3\%の值引き有 } \\
\eta 。\end{array}$ \\
\hline & & 1937年販売額合計 & $\begin{array}{l}568,873 \\
\lceil 100.0]\end{array}$ & \\
\hline
\end{tabular}

注 1 : 小数点以下は四捨五入してある。

2 : 上記の販売先の他, 羅紗に関しては, 長谷川正衛商店, 山本仙次郎商店, 大川慶治郎商占（と もに大阪市東区) 等が, 毛布に関しては又一洋行 (大阪市西区) が, 紋敷布等に関しては田中 与一商店, 村本米吉商店（ともに泉州）等が販売先であったことが判明している。

資料：製品販売先に関しては『昭和 12 年納谷竹織物工場売原簿』, 取引先住所は『納谷竹織物工場取引 先住所録』及び石塚博章氏よりの聞き取り（1989年 9 月21日実施）

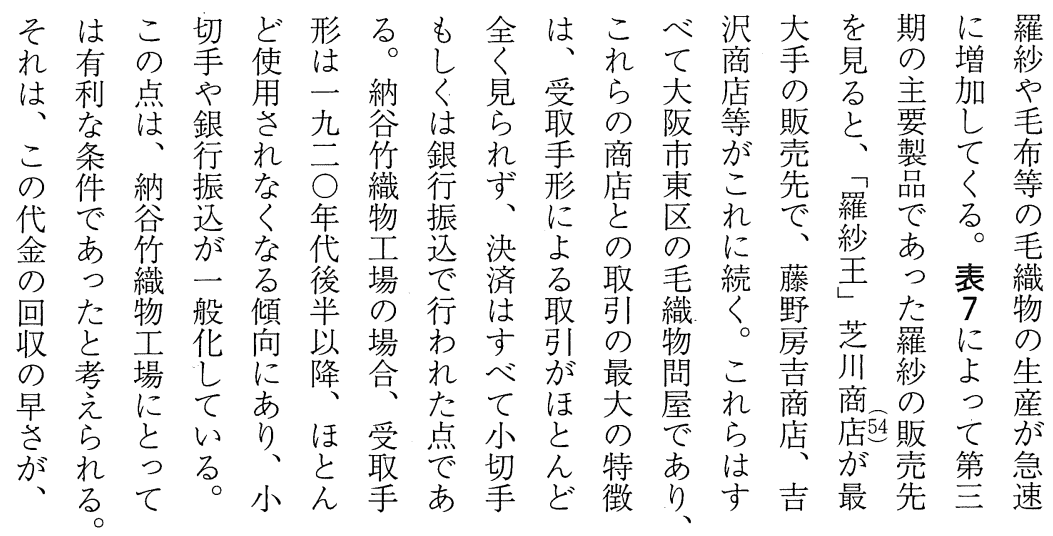


らのい最占市的の店ど等よ 断前 は納経た綿初め次内以あ販内全のく述 い谷営。系にるにの上る売軍く事指るる ず竹の納は綿シ 原問の掊と、た れ織最谷紡系工系屋、考特途品施もさ納 も物盛竹績のアのつ察に絶は見れ 大工 期 織 会 購 は購小少、元れらる一竹 阪場で物社入急入切ら道た本なれよ回織 市にあ工市先速先手、幸わ毛いなうな物 東おる場らににに受こ商け布点かない工 区け一ののつ増つ取の店で工につ銀し場 をる九購 直い加い時には業も行司の 拠綿主入接て して 綿期関な 組毛。の 回総 点系七し購見、見綿载しく合織ま割の資 との年た入よ毛よ織納て、老物た引小本 し大に綿がう系う物谷は道通取切回 た手お系見。は泉竹幸し引毛よ手転 綿購いの $ら$ 全製泉織多商て の織つに率 系入て大体品州物額店軍特物て よ の 商先、半ずの多産工のや徵の手る高 では同は、約様地場売横陸が販形支さ あ、工公化地識の掛山軍あ売を払を つ岩場こべ割の織製金商千るは早がも た田がれて隻物品や店住。大急一た

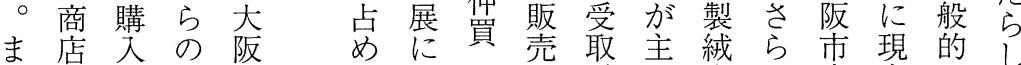
た綿し綿市、よ掛先手要廠に内金でな 量部原問の方毛売沙形に毛問华 あと

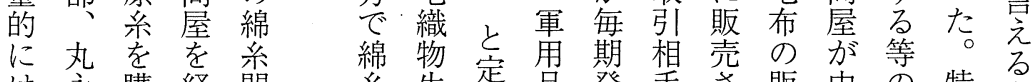
は永購経問 系生式品発手さ販中の特か 僅商入穴屋産华の生でれ売心事にら

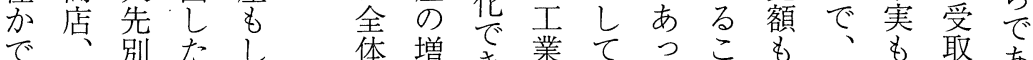

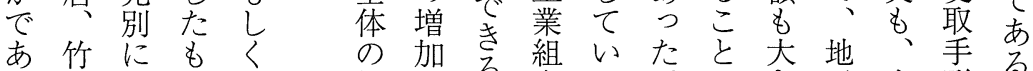

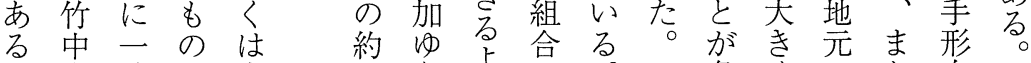

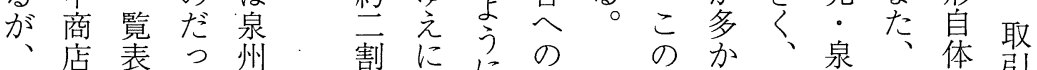

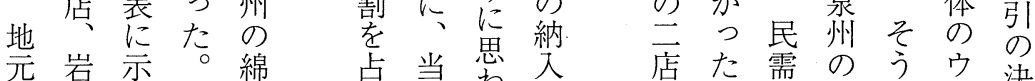
・田し表系如期わ瓜占。而商し工济 泉常た 8 仲に势除地他は店なイ済 州商もは買にはる。け元方大にけト、 の店の、を毛采泉、阪対れは、 綿等で納経䒺系紋市しば非売 系であ谷て まの毛年敷東て 資常原 仲ある。竹購織綿布区原 買り 0 織入系物織や の 難小年

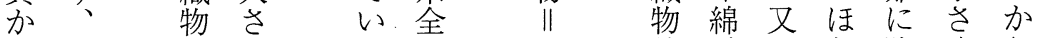

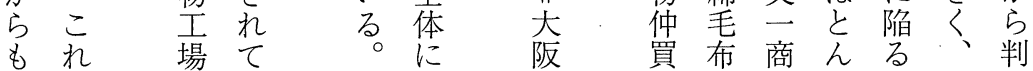


表 8 納谷竹織物工場における原糸購入先一覧(1937年)：上位 5 社

\begin{tabular}{|c|c|c|c|c|}
\hline & 購入先商店名 & - 所 在 地 & $\begin{array}{l}\text { 取引金額 : 円 } \\
(\quad): \text { 数量 } \\
(j: \text { 比率 }\end{array}$ & $\begin{array}{c}\text { 備 } \\
\text { ( )内は商 } \\
\end{array}$ \\
\hline \multirow{3}{*}{ 綿 } & $\begin{array}{l}\text { 岩田商事(株) } \\
\text { 綿糸部 }\end{array}$ & $\begin{array}{l}\text { 大阪市東区 } \\
\text { 南久太郎町 } 3\end{array}$ & $\begin{array}{l}26,661 \\
(4,870 玉) \\
{[6.4]}\end{array}$ & $\begin{array}{l}3 \text { 大紡系の鐘紡(釣鐘草), 東洋紡 (双鹿), } \\
\text { 大日本紡(鶴鹿)が多く購大されている。 } \\
\text { また寺田財閥系の寺田紡績工僘(双鶴)も } \\
\text { 多い。 }\end{array}$ \\
\hline & (株)丸永商店 & \begin{tabular}{|l|} 
大阪市東区 \\
南久太郎町 2
\end{tabular} & $\begin{array}{l}21,232 \\
(3,730) \\
{[5.1]}\end{array}$ & $\begin{array}{l}3 \text { 大紡系の綿糸が大半。また, 和歌山染 } \\
\text { 工(Q): カクマル), 倉敷紡績(馬), 長 } \\
\text { 崎紡織(宝来)等の全国の綿系も含まれる。 }\end{array}$ \\
\hline & 竹中商店(株) & $\begin{array}{l}\text { 大阪市東区 } \\
\text { 北久太郎町 } 1\end{array}$ & $\begin{array}{l}14,486 \\
(2,420) \\
{[3.5]}\end{array}$ & $\begin{array}{l}3 \text { 大紡糸の綿糸が大半。 } \\
\text { 全国各地の綿糸が納谷竹織物工場に販売 } \\
\text { されている。 }\end{array}$ \\
\hline \multirow[t]{3}{*}{ 系 } & $\begin{array}{l}\text { 岩田常商店 } \\
\text { (株) }\end{array}$ & $\begin{array}{l}\text { 大阪市東区 } \\
\text { 北久太郎町 } 2\end{array}$ & $\begin{array}{l}12,595 \\
(2,200) \\
{[3.0]}\end{array}$ & 同上。 \\
\hline & 小山商店 & 泉北郡大津町 & $\begin{array}{l}3,135 \\
(660) \\
{[0.8]}\end{array}$ & $\begin{array}{l}\text { 泉州産か近隣産の綿系を納谷竹織物工場 } \\
\text { に販売。和歌山染工(囚: Øカクル), 山 } \\
\text { 本絹綿紡 績(四):マルカイ), 寺田紡績工 } \\
\text { 廠(双鶴)等。 }\end{array}$ \\
\hline & $\begin{array}{l}\text { 山本毛糸紡績 } \\
\text { (株) }\end{array}$ & 泉北郡高石町 & $\begin{array}{c}115,463 \\
(116,234 \mathrm{pd}) \\
{[27.9]} \\
\end{array}$ & $\begin{array}{l}\text { 納谷竹織物工場はここから毛糸を直接購 } \\
\text { 入していた。 }\end{array}$ \\
\hline \multirow[t]{2}{*}{ 毛 } & (株)平松商店 & $\begin{array}{l}\text { 大阪市東区 } \\
\text { 高麗橋 } 2\end{array}$ & $\begin{array}{c}82,894 \\
(78,633) \\
{[20.0]}\end{array}$ & $\begin{array}{l}\text { 大企業の毛糸が納谷竹織物工場に販売さ } \\
\text { れている。例えば共立モスリン } \\
\text { 栗原紡織(K216), 東洋毛糸紡績 (BHY) } \\
\text { 等。 }\end{array}$ \\
\hline & 木村貞三商店 & 泉北郡大津町 & $\begin{array}{c}33,325 \\
(34,341) \\
{[8.0]}\end{array}$ & $\begin{array}{l}\text { 産地毛糸仲買。大阪の毛糸問屋の扱う大 } \\
\text { 企業の毛糸を機業家に仲介。 }\end{array}$ \\
\hline \multirow[t]{2}{*}{ 系 } & $\begin{array}{l}\text { (株)芝川商店 } \\
\text { 毛糸部 }\end{array}$ & $\begin{array}{l}\text { 大阪市東区 } \\
\text { 高麗橋 } 3\end{array}$ & $\begin{array}{c}26,348 \\
(17,883) \\
{[6.4]} \\
\end{array}$ & $\begin{array}{l}\text { 羅紗を扱う商店の最大手。納谷竹織物工 } \\
\text { 場の羅紗を扱いつつ, 同時に毛系を販売 } \\
\text { していたと考えられる。 } \\
\end{array}$ \\
\hline & $\begin{array}{l}\text { 吉田十郎商店 } \\
\text { 紡績部 }\end{array}$ & $\begin{array}{l}\text { 東京市 } \\
\text { 千駄ヶ谷穞田 }\end{array}$ & $\begin{array}{c}20,354 \\
(21,414) \\
{[4.9]}\end{array}$ & $\begin{array}{l}\text { 自己工場で毛糸紡績を行っている。Y120 } \\
\text { ブランド等を販売。Yは吉田の頭文字か。 }\end{array}$ \\
\hline $\begin{array}{l}\text { 众 } \\
\text { 絹 } \\
\text { 系 }\end{array}$ & 紙谷商店 & $\begin{array}{l}\text { 堺市 } \\
\text { 甲斐町大通 }\end{array}$ & $\begin{array}{c}10,470 \\
(17,744 \mathrm{pd}) \\
(2.5]\end{array}$ & $\begin{array}{l}4 \text { 番手のものばかりであるので, 経系用 } \\
\text { に使われたものと考えられる。まだ本格 } \\
\text { 的には使用されていない。 }\end{array}$ \\
\hline
\end{tabular}

\begin{tabular}{c|c|r|r|r}
\hline \multirow{4}{*}{ 総 } & 綿 糸 & 83,550 円 & $14,946 玉$ & $20.2 \%$ \\
\cline { 2 - 5 } & 毛 糸 & 319,999 円 & $320,598 \mathrm{pd}$ & $77.3 \%$ \\
\cline { 2 - 5 } 計 & 人絹糸 & 10,470 円 & $17,744 \mathrm{pd}$ & $2.5 \%$ \\
\cline { 2 - 5 } & 合 計 & 414,019 円 & $487,800 \mathrm{pd}$ & $100.0 \%$ \\
\hline
\end{tabular}


注 1 : 小数点以下は四捨五入してある。そのため, 合計の数值は完全には一致しない場合がある。

$2:($ )内は取引数量, 〔〕内合計金額に占める構成比である。

$3:$ 綿系の取引数量の単位は玉，毛系はポンドである。ちなみに 1 玉＝10ポンドである。

$4:$ [綿系 $]$ 上記 5 店の他に, 大阪の綿系問屋として, 泉(株)日比谷商店(西区土佐堀船町), 八木 商店 (東区南久太郎町 2 ) が, 泉州の綿系仲買として, 曽根勝商店(泉北郡大津町), 小橋商店 (同), 千代松商店(同)の計 5 店がある。

[毛糸］上記 5 店の他に，大阪の毛系問屋として，三京商会(合資)(北区旅籠町)，(株）安宅 商会 (東区今橋), 岩田商事(株)毛系部(東区南久太郎町), 高島屋飯田(株)大阪支店(東区横堀), 丸紅商店 (東区本町) が, 泉州の毛系仲買として, 小川喜商店(泉北郡大津町), 前山新之助商 店（泉州？）の計 7 店がある。

資料：取引先名, 数量等に関しては『昭和 12 年納谷竹織物工場買原簿』, 取引先住所は『納谷竹織物 工場取引先住所録』及び石塚博章氏よりの聞き取り（1989年 9 月 21 日実施），商標に関しては， 大阪綿系商同盟会・大阪綿布商同盟会『日本綿糸布要覧』(1927年)，大阪綿布商同盟会『昭和 9 年版日本紡織品便覧』(1934年), 紡織雑誌社『日本紡織年鑑・昭和 6 年版』(1930年), 同『昭 和15年版紡織要覧』(1939年), 岸原吉次郎 P大阪府泉北郡大津機業研究』(1920年), 梅浦健吉 羊毛工業』(現代日本工業全集第 9 卷, 日本評論社, 1935年), 大同毛織株式会社資料室『糸 ひとすじ・上』(1960年), 日本毛織株式会社『日本毛織三十年史』(1930年)及び『同六十年史』 (1965年), 大日本紡績株式会社『大日本紡績株式会社五十年記要』(1941年), 霧島紡績株式会 社社史編集委員会『霧島紡績七十五年史』（1968年）等を参照。

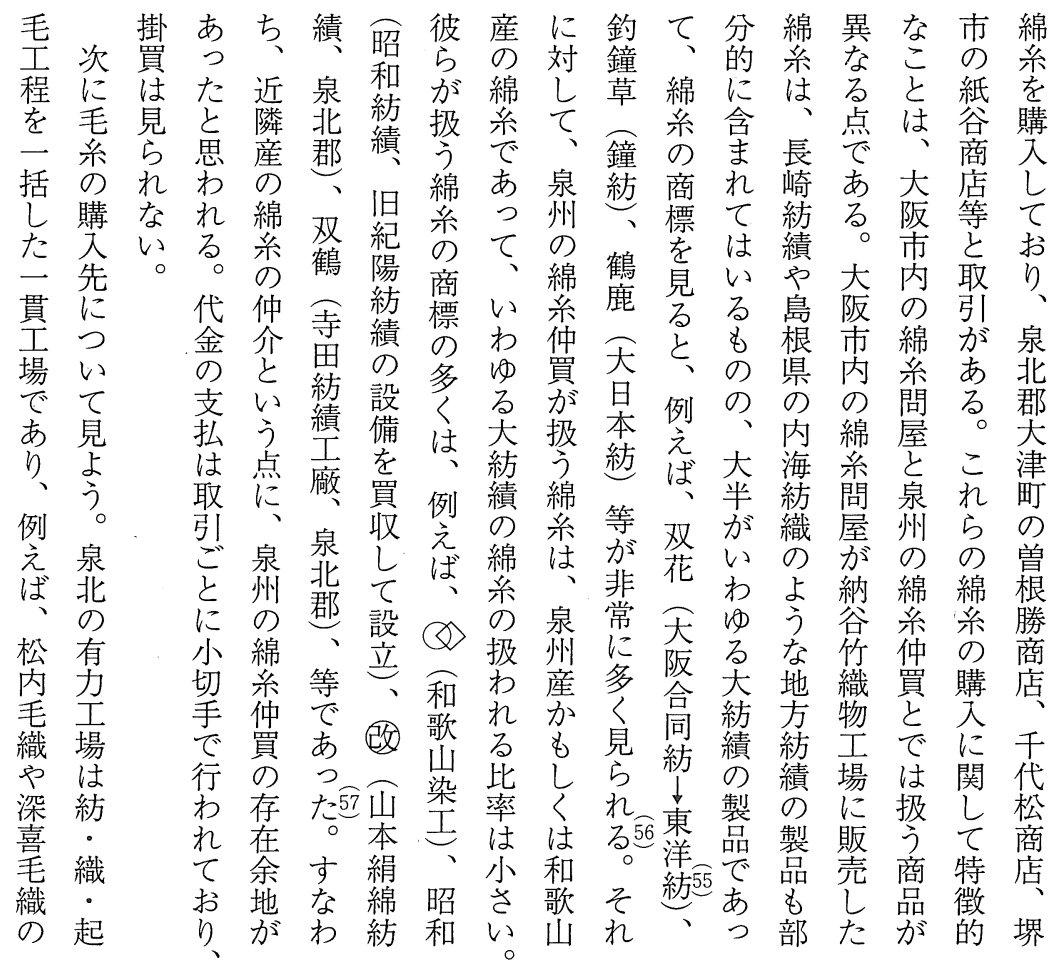


第26巻 第 4 号

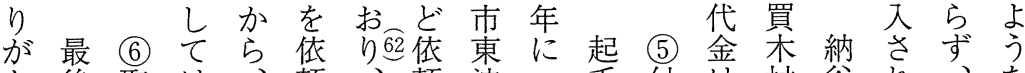

な後取は、頼、頼淀一毛付は村谷れ 、な

いに引第泉しそさ出 ○ 加属 月 貞竹る毛規

。当銀至北たれれ区の工加の严織点系模

し期行期にもゆて機に工二商物にはの

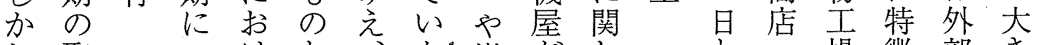

し 取 けと淿徵部き

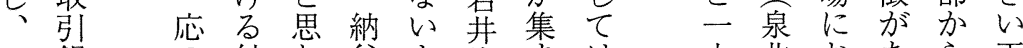

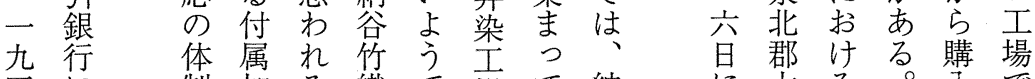

淛加る 織で場て 納に大る。等无

○つが工。物ああ設谷 小津毛化

年い整はま志る大立竹切町系方毛

代て、備、た場。阪さ織手、少、糸

に見さ染、は一染れ物はに芝購は息

はよ和色晒、九東、王总入自

こ た 等白技 三 区 起場

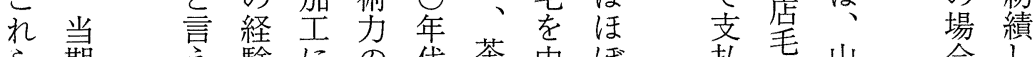

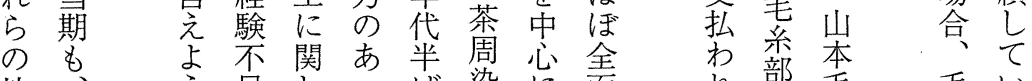

地、う。足しつば染に面

元特ののたた た の 整的

銀地術地阪 つ 加地

行元を元市て 愛 工 元

の.

他泉

に北

他で内も知をの

三大

和 津

銀 信

行用

久組

太 合

郎に

町大

支き

吉依

初存

期 ᄂ

はい

鴻る

池 点

銀に

行は

地は少、県業大

域な毛泉一務津

へく織州宮と川

依、物で市し製

存辻先は䋐

し阪進満等 w株

は晒地足にた可式

す工域な依。会

る場で染存一社

も立色方充

の大つ加て 依

の阪た少 お捺存

起市尾 ば 、染し

毛にのき地工い

等依染な元はな

の頼色かに稲。

主し 工要て 場た 加染 社

ないにと要吉は

れ部毛

て大采

二阪 績

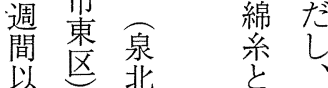

上、郡納

の 吉 忠 違 谷

長田岡期十 町吕

に郎、文物

及商平方高

忍店松 程場

掛紡商度に

買績 店 資 関

は部店 吕 し

れ京市板毛

な市市ば系

手果紡 紡

つ駄区 績 績

たケ、会は

技る染言 が場

術。色わほ 九

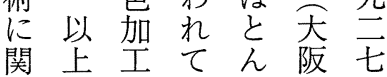

谷羊泉社行

州少

等の られ

で毛直て

あ糸接は

とわ

る仲購 お 
経 営史 学

織 泉

物 北本

機 稿

羅業 で

紗内は

の

と 尉別

主層

力 構 例

製造を

品検

転 中言

換 間 る

七層气

い当で

くた

点西

に層大

認穴戦

め、間

$5 こ$ 期

れのに

た層抒

以特る

下徵 泉

、は北

本、機

稿一業

で九 の

見言動

い○ 向

た年を

さ代 検

れに討

た綿 U

間 物 き

層綿た

変綿本

化布稿

を、で

敷 検

納 布 討

谷尔主

織らの

物毛は
地のて点近完の定力好主綿第に北屋隻

: 術泉特産式織条従言扔通銀 泉的州徵産华物件期い常行 州依にがのでのを路のての難 の存依あ綿き導背線納も取波 五地に存る系上又景の谷該引支 結 銀っで、がうでに採竹当銀店 行てい大あ原っ納势物るが登 に泉た阪り、系た谷っ兄の地場 加北が市前の。竹こ場で方し 語穵毛捺の前購製織毛毛経な行 取

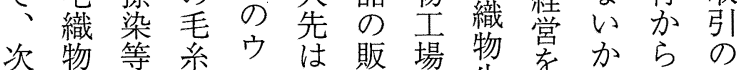
第に年問工賠場生を名らの に関経屋イ綿先業産ま思都㧘

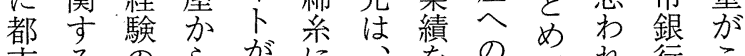
市るの占に老の轱てれ行こ 銀付浅の韭関毛急転抒る的机 行属い購常し織速換ふ。と ら の加そ等にて物には方方の

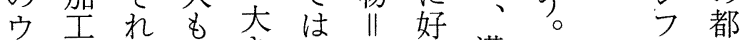
土は以多き当大転満納卜市 イ 外〈 卜応の見。阪市也事含竹て衡 がの技ら毛市内变松いに 大完術系内人次 き成はたにの尔そ降第傾第 々尾。関綿切しの第向に

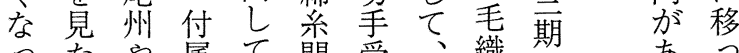
ったや属て問受、織期市っ てと大加は屋最そ物毛るて い言阪工、些需織元い

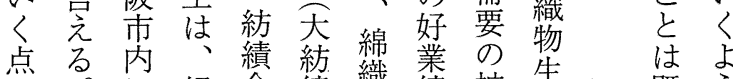
に。に経会績織績拡橉既う 特さ依験社筫物縜大鹰にに 徵ら頼のか綿川原や主指な

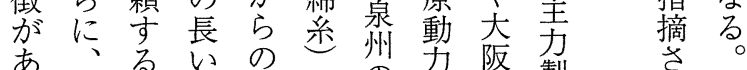
あ、取得直々の方製机戦

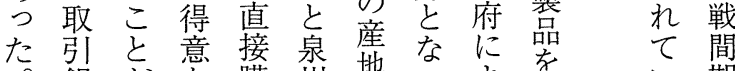
銀がな購州地っよ境 い期 行多起入の織たる転るるに にく毛の綿物も羅換古菂は

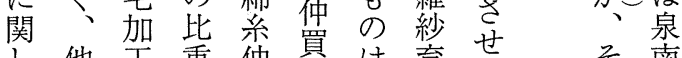

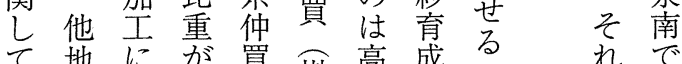

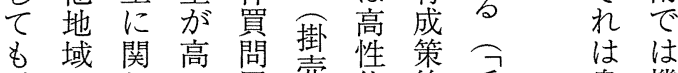

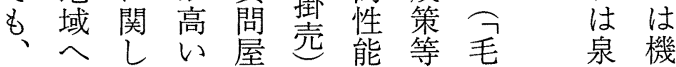




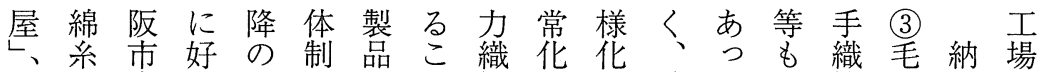
問内転軍がのと機しは綿た、機織谷の 定屋 さ需泉販が㤎て重と地に物竹経 式天蛋せの州売で使い金布い元よ主織棠 花大切る増に㤎角た融六のつ導物の 华紡手。大抒行たさこ恐混る泉て経工変 き績受そやいわ。れと慌毛た州生営場遷 きの取の大てれまるに及綿ろの産期のを よ綿契阪次、たよ対び毛う商しつ経見 。系。機府第原方守昭布。店て二嫦る 付 + 綿 属泉物つる備入多っ開慌毛製行、三 (1) 加州川た泉さは椂た策下混品に期了綿要 工 の泉も北れ綿化。とで織多依末策三織約 は綿州の機つ系はこし機肩様存利分物し 不系のは業つ䧇製のて業掛华产年主て 不慣産、育あ中品製採地等経るは来導お

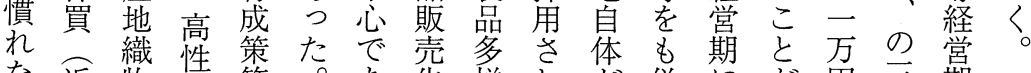
な近物能等。あ先様れが併に吕方期

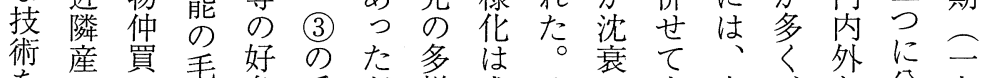
を原織条毛㤎様成々し生少、分九 尾綿掛轿件織、化功して産数こま割云 州系売甬の物大ををて先し商のだ゙

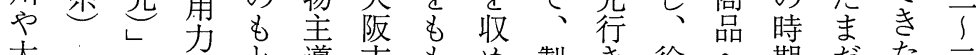

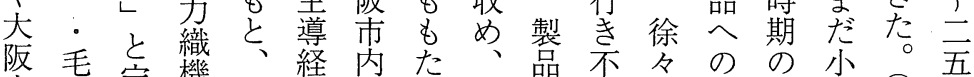
市系式機毛営の継品安に依納規 (1) 年

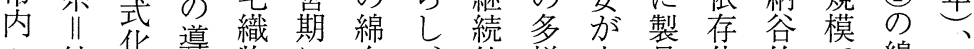

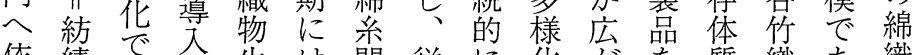
依績きで生は問従に化がを質織あ織 (2) 存会き京産菿来減にり、多老物る物製

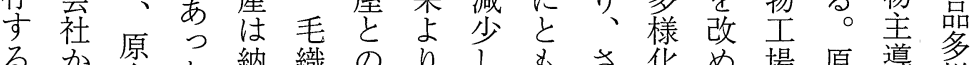
るか原た蒳織の とのの購製竹生引多いるにる従経購営化 に直購製織産がくたて納こ来営入期経

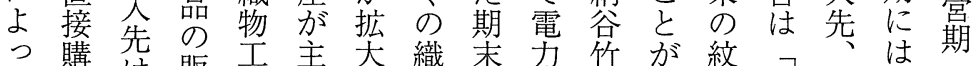

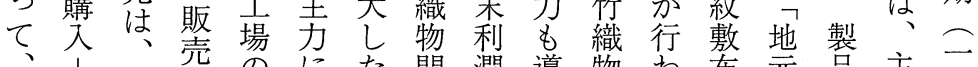

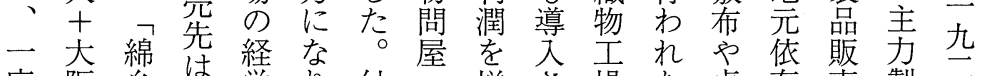
応阪系は嫦り、付立増さ場た卓存簩京

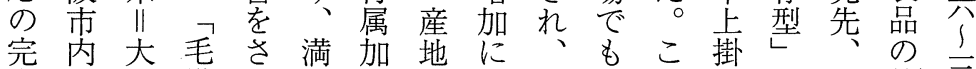
成の阪織ら州工仲転木減の祀の取紋文 を毛市物に事も買ざ鉄收製け経引罊年 た問の大速以のの製経多な点隼を、 
経 営 史 学

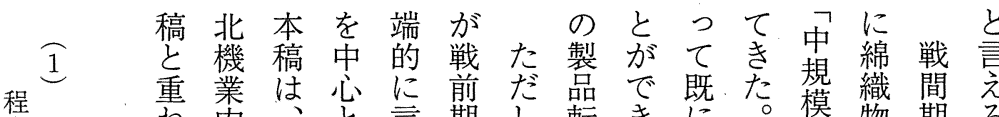

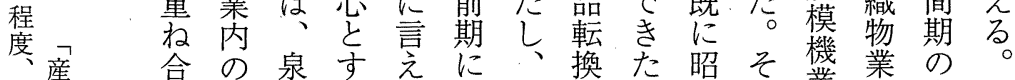
も地わも北る将ど本加。和し並以泉取 炎経 う機っ、の稿、戦戦て家上北引 は営る—業第こょで毛後前、をに機 銀 そ艺方を屋のう考織の期泉を急業行 れととの担層口な察物泉に北忠速はも

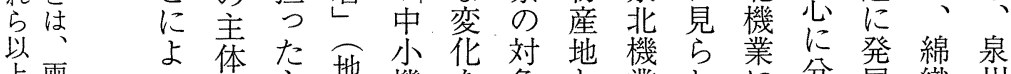
上自っ集地機を象と業れに分展織州 の大戦て市体域業遂としの打析を物の 織間、るの的家げなて動そけす遂業地 機期戦半にたっの向のるる将方方 台に前第分現をのた、に意綿こた発銀 数広期垈に珼中かの戦絡味織とと展行

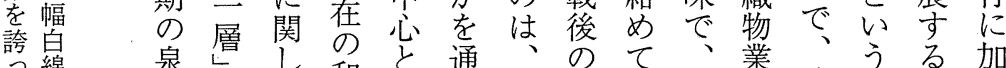
綿 た布 織 比

布 較

専 的

業大

の 規

い模

わな

雨工

万場

産で

地少

機品

業 種

家大

こ星

旁産

ある

る 地

。域

泉に

北抒

にい

拉て

る有

ᄀ力

産紡

地 績

大 兼

経営

営織 に炎 泉曾、し 和と通、先て、業

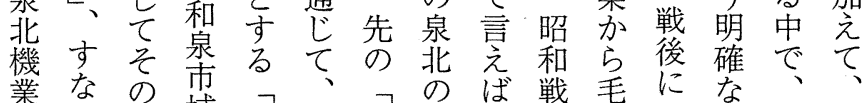

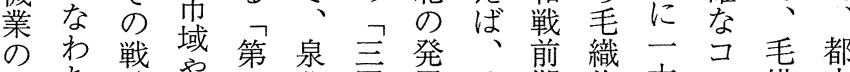
全ち前岸屋北層展々期物大会織市

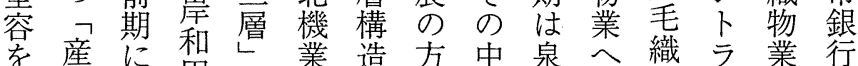

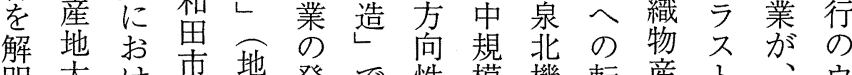
明大汁市地発で性模機転産卜、ウ す経る域域榐言老機業換地で生工 る営動分に的の完指業のの泉特産イ この向帞は側ばし家一胎な徽額卜

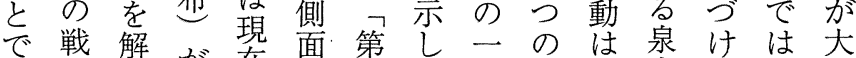
あ前明が在を寻た九転、大ら綿き る期 し リ検層言換中津れ織 にた泉討是と点規市よ物な

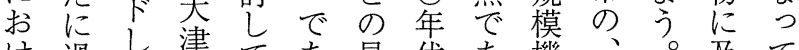

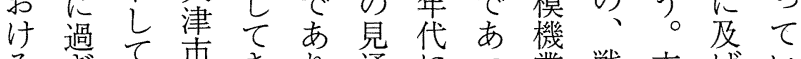
るぎ市きり通にっ業戦本ばい 事なき域た、通た家間稿なっ

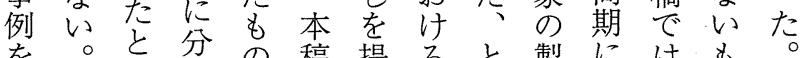

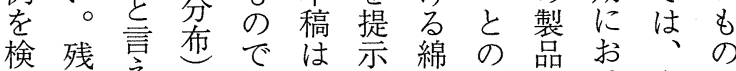
検残言布では示綿の品挍泉の 討される。市こで織結転け泉の た課し産。の泉占をへ動津一 稿題た势北第う。毛起努を向市厹

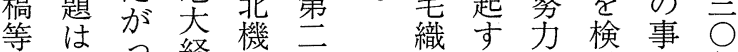
の経業層物るに討例年 論泉て営栄 へょしを代 


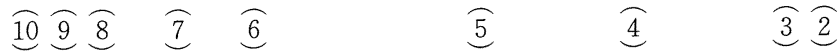

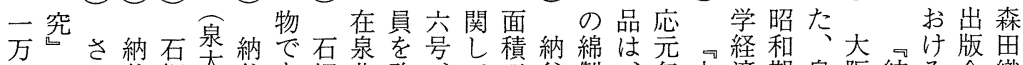
以天に寿博涪寿る博郡め

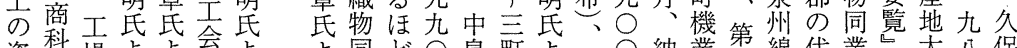
資科場よよ議よょ同ど○島町よ毛○納業第綿代業甞大几保

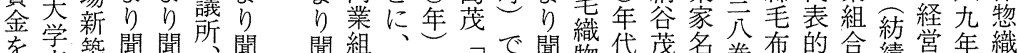
を綷築聞聞所聞聞組泉的で聞物代茂名巻布的合績営年織

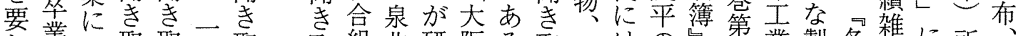

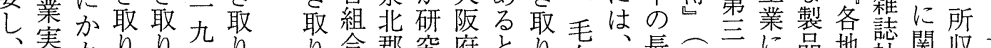

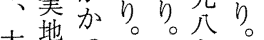
き調た䒨な な查亲年拈

場一五吾窇吾 り合郡究府とり布・長二比品地社関収大 員に水に言二亦白男无四执で織埜しの鳥

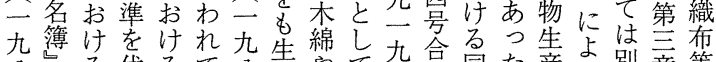
几、る代るて几産やて年併同た産れ別章等

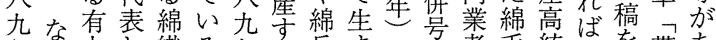
年ら力し織る年る兵ま及者毛統は、を带あ

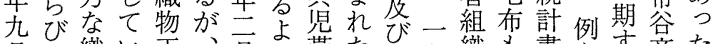
当年品 と年余 数一余

方西

P四西

時頁金

に額

はよの

一垫き

号姑さ

盆泉に

北 8

及望注

会蛙

兴織

が物き

あ場市

たをる

経岸

机守原

てる吉

wに次

るは郎

㕺大天

、正阪

納中府

谷期泉

竹で北

織 \& 郡

物少大

工な津

場之機

のと業

新多研

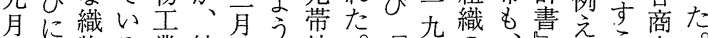

梅 前物る業納三に地。气几の、泉几店

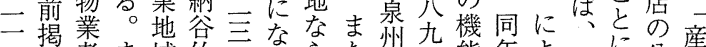
日揭者ま域竹百ならた名年能年よ一に分地

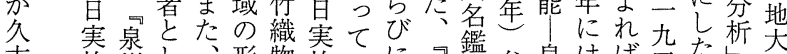

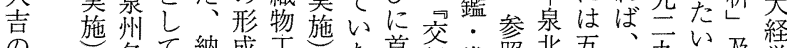

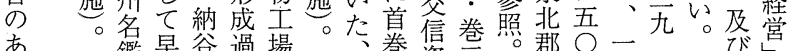
な鑑早谷過場泉々卷凟堂

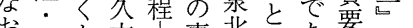
挍巻加吉事北京㐫要物強三和 党は二例郡劣り多 石巨地尔も无。、商刊 塚一位一兀乞機一王関 氏五老八○れ業 は吾固九年に家 頁め代該の

九重西 害昆 半县て尖当

年、新 界 フ 綿

代一聞 世照い明泉守身 紀照た治大る階 に津立層

初九社 頭二泉三近のは 州二郊と主 織年諸思に 物に村わ自 工設のれ作 業立事る農 協さ例。上 同れ|泉層 組たし北部 合泉分郡か 所北人のら 蔵郡文機中 織地業小 昭物理家地 和同心主 は年九 文至 に三年布さ輸存 加貝 之一希て依注 てょ五 紋ば頁 敷、参 希 納照 模贫納 様織谷 入物 久 の場は

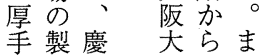
年組四身等 合芘所 月の巻層有 現役第に地

同が六四 業? 組ジ昭年 合ア和の の. 一泉

限アこ北 改力の物 組地泉業 と域北の 日一綿 輸 本輸業出 毛出の依 敷れ出度 工い存四

第 に 四関 章 ᄂ ᄀて 旦は 綿 阿 織 部 物 武 業司 挍日 け本 るに 打 産け 地 る 大産 経 地 棠 綿 組。度七織 組拙卆を物 合稿二\% 参業 機 ・䒘照展 能反一動\%る開 動 \% る な こ恐慌あ 大期る泉京 阪加北大 に学 


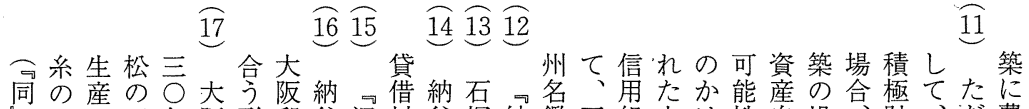

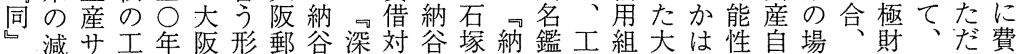
昭産イ場代府の船竹喜照竹博谷・場合津つも体合工政経しや 和去ド経に内模や織毛表織章竹巻ので信き否はも場と綿、さ 四らで営は務様日物織に物氏織二拡あ用り定、同の満系これ 年供あを不部の本工百記工物し張る組しでこ様新州づのた 二給る大況っ入郵場年載場り正二と合なきのに築事か新金 二給中きの昭つ船の史さの聞場五土推のいな新手は恋い築額 正不小くた和た船紋経き新六地測理。い築元こ以のには、

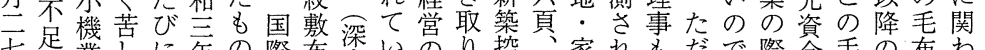
七是業しに年の際布塣いのり揬家れもたで際金手の布わ泉 且ににめ発・が汽は㲔る害 なとた生大孔船、手壳態 等るここ機腐势朝常株金取 参はは業商国鮮よ会や引 照大価地勢鳥郵り会買先 阪過きに概で船か社掛に 朝哈取打要あ等な一金関

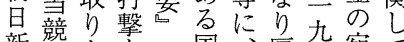
新踭加国厚九宛て 聞々ら与事学示手门先は 泉々もえ九フのの年等 泉狆確た公会綿製八は資 版に認ご年ピのの㤂じ的 昭值た、学敏頁と約 和崩。納七にクで照すに 四れ一谷八に入あ照るよ 年㤂般竹! 販りり直 七㔔的織三壳の、接て 月場に物七さも表宊不不 云経不圭れれの面䦭明 ○嫦況場頁たがを接の 旦学下の参り高起 苦で経照て級毛 及難は綿にま営ま寝て びに綿にまいた室て 府落価き原納寝合 下集格之原納具心 のれ㤎影料谷とを 織たあ響綿寿し良 物こまし采昌てく

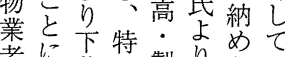
者に落に製りらて が関落に贸聞れる 操七な九䋟きたる 短てい空努取同 には、のーり。更 反例に年九。 場 対例対代云雀の 资分部 を大 をき にく 乙 全 作面 作的 及屋る務、あにに元軍・る北 参びの。め納っ数よ資需メ資に 照伊購こて谷て方っ金のル金㧍 賀入のい竹、円たで拡卜のい 上に点た松現のと賄大ン出て 万際はかの在支もうと等所は 次し今ら実の出考こをににか 郎て後、父とが点と背つつな 他はの外・こあ点が景いいり ᄀ、課部久ろつれでにてての 大格題か吉工たるき毛織は金 津好とらは場と。た織物現額 町のしの、の思しこ物消在で 誌資て資自新わ加生費のあ 金後金ら築せしに産税とっ 天融にの織費る、つががこた 津通譲導物角ほ一心伸撤乃考 町者る入六はとて張廃不考 役でこが場自大、はしさ明え 場あとあを芑き聞たれでら 一たした経資減和きたた取めこるる。 九。た守等七りにと。 至以いする賄し年か機が浜

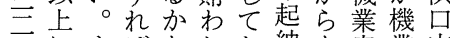
年にまばたれ扮納も家業内 関た、わたら谷確の芜閣 二し、資らのず竹認手のの 王て大金、加、松で元負緊 二は津の一、何決きに担縮 了、信出九そら算るかを財 二納用所三れか簿。な軽政 八谷組は三との・しり減政 しは た解 も琞 の で でき あな るな の衤しのう等 大ば、納年向敷 会綿方竹帒㔔布 六寿合納○も形奥たのし策 頁明は谷大外で恣資、に 参氏中本正部外にっ金加基 照よ規家一か部よて蓄えつ り模か三らかれ、積てく 聞以、このば納㤎金物 き下も年資資谷あ輸価 取のしに金金納竹り出抑 り機〈当導導谷織、再制 、業は地入入竹物あ禁策 前家こににが松工る止の 揭にの設よあ本場工以一 泉っ津站っっ人の場降環 


$$
\text { 27 } \widehat{26}
$$$$
\widehat{25} \widehat{24} \widehat{23} \widehat{22}
$$

$\overparen{21} \widehat{20} \widehat{19}$

$\overparen{18}$

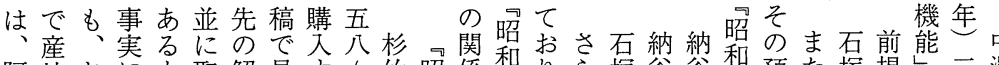

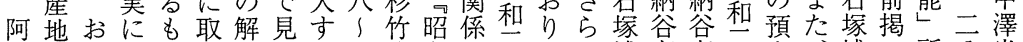
部仲そょの引秎るる五清和で年々に博寿着年金博可所几米

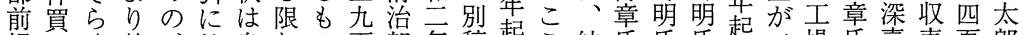
揭吕く整、就泉りの頁郎年稿起こ納氏氏氏起場氏喜表頁郎 書残は合そい北性はにっ起に綗で谷よよよ愁九のよ毛3

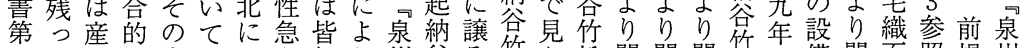

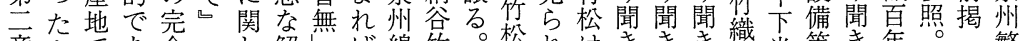
章上五賁二人解产は綿竹。松れはききき織半等き年。敏 をうのるな二て解と笔織 参で小。消旮はでい泉布物 照あ口儿滅变妥あう州工工 る取たは旮当りのの業場 各引が一年等綿概決 依己厹五な无般系略算

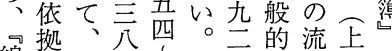

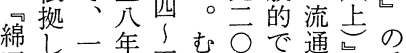

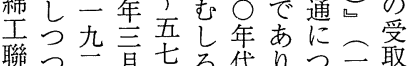

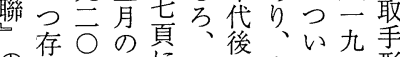
の続年长泉半泉て三形 解乙代綿古北栦は王の 釈学系るにらで、年欄 はた占配よ関まは比参 泉と点給う总産比八照 南考䟽にて年地較頁 に年制機代代綿尔 関る代規機、に系尘た しべ則業大扮楅梘た てき扮家阪心買模し はでい塞と控ては場 采はて施綿挀泉ほで本 多少降問検北消綿 るろなの屋事に滅縞織 もうくこの局は状簡物 の加々直虐態閏業

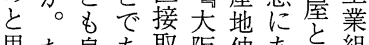
思た泉あ取阪仲あ政 わた北る引を買っ引合 れしでとが中势た可連 る、は解增心多乞し合

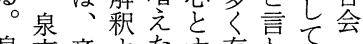
泉南産子た孝名和 南に地るたる続れ势綿 の比仲のめ綿して 、只 産し買が産系ていて聯 地罚、地布いる仲 買泉数稿買び消し商旮 塄北はでは綿滅名を旮 動の減明数莫しし通云 向方ららを大て心学 にがしか隇小はそて卆 関後なにじの打れ原厹

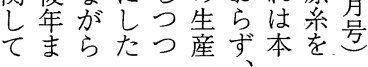

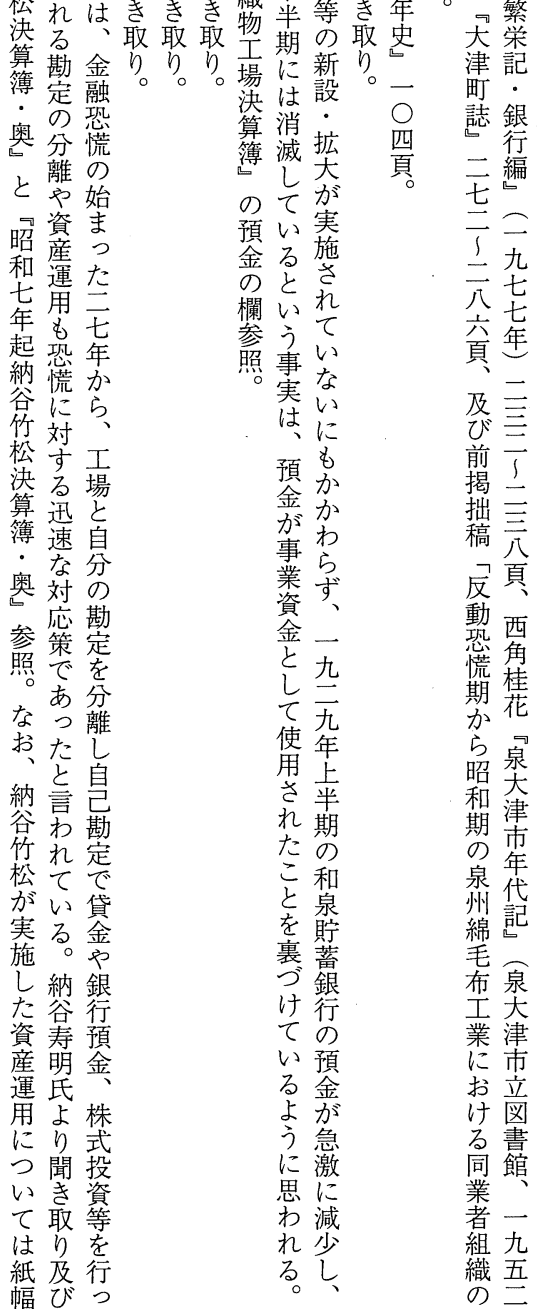


$\widehat{36} \quad \widehat{35} \quad \widehat{34} \quad \widehat{33} \quad \widehat{32} \overparen{31} \quad \overparen{30} \overparen{29} \quad \widehat{28}$ 拿に花し考納投どる展吾な加毛上そ!起 連伊於の納てえ谷下急と開泉頁こか工さ前布しの前っ収毛納 合東け高谷成占竹し激いに北参れっにら揭産っま揭大可し谷 会光る騰竹功れ織てなう関は照らた関にっ地たま津参た竹

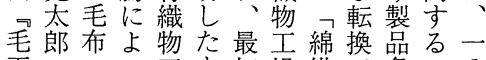
I $\cdot$ つエも初場織で多一八 聯日綿て場のにが物は様事八 史本毛泉がが触っにな化例 羊布北毛あれ産加いはと年 所毛の郡織つた地え。代 収工採特物たよ大毛多泉て初

業算産生こう経織額大|頭 一論哭の産とに営物の津し妿 九洗綿には沿を資のつら

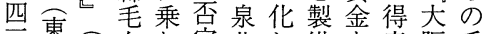
严龺二布り定北し織を意阪毛 年洋云がだでになす投な大織 経旮採しきおかる下起学物 参済百算たないつ製し毛経生 照新年割理いてた品て技済産

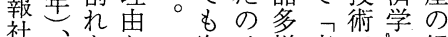
社、をと資は様産で帒経 一及起し 金第化地加第験 九前して 五揭て時 七年年い代 年大た 津 事 要 五町実請

四綿夲唔 六毛指と 兊希摘い 頁機業方 調文を お査献指 びがに摘 フあは伛 本る例の 阷离は 物筍石

生崖博

額毛章 布 氏

大 業あで

日組 る

年合ま

織過た

物 圭数原

業数原

組年綿 分資ほ営れ卷し で金う巻て あのが化子四拉 れ問、し起塄り ば題む綿毛 森䟎し織 8 一拙 田第乃物の元稿 織二中専し九 布に署と八大 紡機とい八正 久毛業なう年期 保織家る点参に 惣物によで参お 織製とりは照け 布織っは技、る 、をて、術紋泉 大可は従的敷州 鳥能自来に布綿 織に然の連に毛 布すで工続加布 等るあ場しえI の技る設てて業 よ術と備いこの うと考にるれ展 に経え比のら開 ᄀ験ら較で紡! 産のれ的あ毛泉 地問る少つ製北 大題。額て品綿 経でたの、を織 営あた資そ生物 るるし金れ産業
製たて表州しめ泉深物 嵒た、 4 名て、呈仕 の、毛か鑑評一に織上 利一織ら一価九は百合 益般物は巻さ元で年資 率的先尾云れ にに進州しる年な社 関は地銀一こ代い六第 し.. 行五と中が六一 て付尾と六に後、了回 は属州の頁な期同六営 、加に取参っ以書八業 猶贡引が照た降は頁報 行尾る存まと洲大及畫 雄州程在たし毛津び

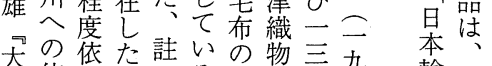
津依存このる声仕二元輸綿

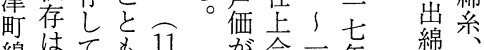
綿はても 11 が合三年 綿

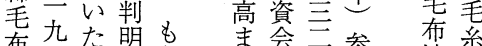

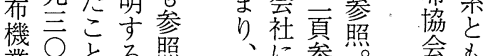
業年とる照一点。検も 調代一こ 查前証れ 究平左は 降な納 天にる䜌 阪多占竹 商々う織 科見に物 大 5 \& 学れ思場 卒たわを 業もれ含 実のる念 地と思加泉 調思、北 查わこ機 一るご業 九兹は体 三绦明が 八述確 年。に不

は得

六 解手

六明な

少垈
起 物 場

のに

がら 基ず 本泉 に北 な郡 七津 い町 るの 。製 ᄀ嵒 查 緯 筫上㑧基系 否仕湘基系

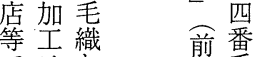
ではと揭手、 泉あ津泉経 州ら織州系 毛ゆ物綿は 布る仕毛二 が品上布六 販質合王も 売面資業し さで会概く れ見社略は 、違は 泉え同 北方族 郡ば企 大か業 津りで 町のあ は高り、」で 本品記二そ 一に述 二れ 
第26巻 第 4 号

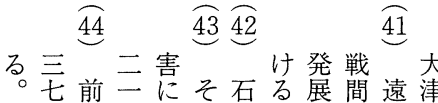

年掲日依の塚工期州商

にコるう博業参にや工

は深二大ち章試照お播会

喜二阪主氏験”け州議

軍毛光産四よ場こるに所

用織吾業年りのう遠お。

毛百吾のの聞役し州い泉

布年箥減き割て織て大

一史に害収取にみ物も津

七攵に概はりつる業、瀻 第れ況、いとの. 維

一四证室文て工構業産

七編は、至献は業造試業

七を泉台台で今試と験の

枚参永九風は後験運場歴

照帮盲に、の場動の史

軍照郡四よ例課の動果。

用納敃っ䟎果すた同

帽谷け九てばとな経し商

子竹る九泉前し営た高

地織紡百州前てた志役会

严物織頁体揭後役喿割議

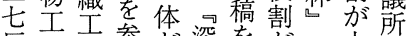

反場業参が涾をが六大 1

を留照浸喜期重巻き $\mathrm{F}$

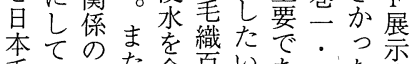

毛も被た含百いあ二た物

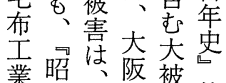

組和三府害第

合二組秷喜严

泉年六部受を

北納場統た参

郡谷場計た照

大竹一課め

津織八風で

町物八風あ

工永る

に場円害と

納売余二推

め原に因測

簿上岳旁

一步産れ

七か。業る

方被

円算害大

余出統阪

のし 計商

売た 昭会

上と告会

あろ 九所

げ、年

七一風

い九月水 た五い
号こ釷会

$\overparen{40} \overparen{39}$

$\overparen{38} \overparen{37}$

館阪こ前村洋繁デ年てざは装日年政 こ合は及阪揭部装華、。い、、本一治

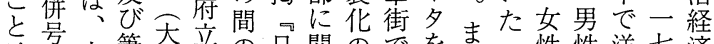
は号山筆大立蛓の旦関のでをまっ性性洋七済 泉一崎者在㵶事本し浸の提た㷖のに装严研 北九広の闇工情羊て透数供考和中はが了究 た六奛聞織業に毛もは値乙考女でか本一所

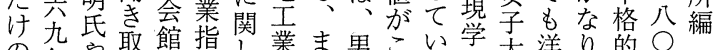
の年や取館導し業ま男こい学大洋り的○ 特年阿り一導て史犬性のる。開学装普に頁日

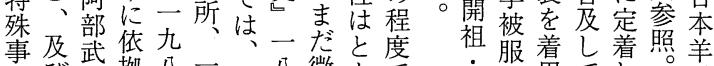
例び司拠八二公微も艺 と阿氏。五九大五々かあ は部が年六阪頁たくれ 言前指、七府参る女ば 完揭摘 な書 し い第て ろ章る。 门播山 在詶山崎 来 綿広 産織明 業 物 に業両 おの大 前年立照も性 前、瀻。のに戦 揭維で関前 深梅昰 あし期 深村業つてに 喜衡指

毛平導 織翁所 百と沿 たはお 之判、け 判まる 断た㫛 史阪要 、毛覧 泉織
今学用 $\tau L$

今研しいた 和究てたの 次窒たもは戦 の近もの後 服近の、柋東 装帒は它洋 調早女性と経 査本子にで済 は䏕学はあ新 上装生ほり報 掲史にと!、社 表、ほん戦 の一ほど前 よ九限普の 饥最洋六 
経 営 史 学

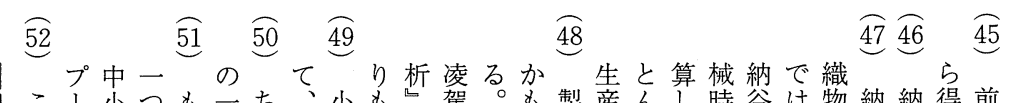
$1 こ 1$ 小つも一ち、小もに駕。も製産んし時谷は物納蒳得前 期のル企にち の場業々総み村隆般至るれれ専等大も比織通場竹竹な 総合との信ん資に隆太的夌こゆな業の勢、例物常決織織製昭 資、い中合、查、英郎に経とえいの上に総法工算物物品和 本当うに薄筆に半、つ高済に、。納昇影資等場減簿工工で二

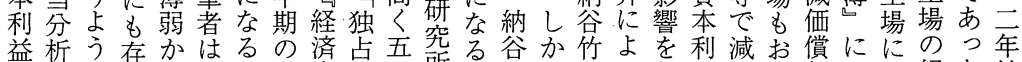
率のな在ら総。総成資了所の竹し織つ与益価そ却は関経た納 根画年く資資長本七各で織な物てえ率償らは賞紋谷 $\|$ 拠二方本 と的金利

t なない融益 期る存う面率

のの在のでの 総はではの比 資以は名不較 本市なゃ利の 回のく、等み 転関そりのを 率係々無事 /式の無実。 $\mathrm{t}$ 㤎内視昚て |成実えあ中 1 立はえる小 期立多な点企

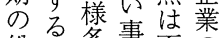
総己多事否息 資と彩実定優 本穴ででで位 回あ゙ああき立 転るるるな説 率るとしこ娖 $\times$ すうし能 ×な事允態 てわと実しあ 期ち章は、る の定意戦がと 売美味戦らは 上式姜前、考 高式る。期最方 利変の毛文 益形中基い 率形小基な 率し 企的い

$\mathrm{t} 、$ 業な。

$1 \overparen{t}$ い恣資

期期 わ本企

ののゆ利業

売総る益の

上資過率経

利利剩高 難

益益労いの

率率働 企 理

が $\mathrm{t}$ の業由 本のと\%各あ物が工償なは却く非中て分敷竹 回定所程年りエら場わい僅費ど常小は析布織

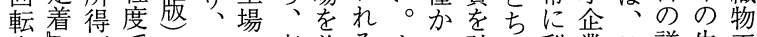
率し再でによの東兼るま一計ら利業純詳生工 は東分あにり数洋営こた」上か益で利細産場

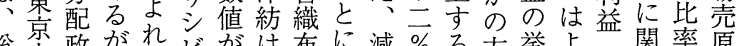
総大政が注ビがは布に減％る方挙よ。関率原 資学策々ば、東当华な偠程と法がく

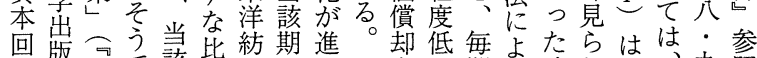

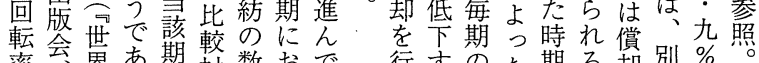
率会界亦期対数おで行すのた期る却別\% 。 II半九一た大とをるたと価の方利をまの 期七九と織な上織と、け償と挙に益期で頃 売㫐六し布な回布は結で却思に省す低に 上年至て会でる中い局あ費わ行決ある下は

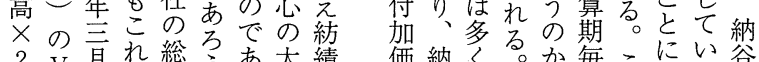
$2 \mathrm{~V}$ 月れ総うあ大績価納之。か毎こにい谷 . も号は資々れ企企值谷とち、にれしる竹 総参、表本と判ば業業を竹もなあ減はた。織 資韶岩中利䉼、でで 森照波崄断そああ の書ら率てれるる 式店明は、は忝東 で明五東、満洋 表参 $5 \%$ 洋と織紡 さ照か程洋り物と れ荌等比 るななで取なよ較

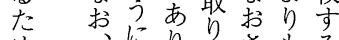
め、にり兵毛る 半容洋天げず遙こ 䔮亮紡満た紘にに 売のの織ち専高対 上論れ物な業いし \|存々み大資は 総発はれ企本、 資展及は㗼利批 本さばこ本の益判 回世なれ邦数率の 転たいら事値をあ

率業の業をある

の績企成遙げと 増織至みる価批い。物 妿物 $\bigcirc に$ 償判贡 さ場○官設費あの場 せ場邑定設費あ 毛 こ関程法をのと織 と隻度使費こ物 にてで算い用ら倍的 なはあ術捨がか生 る、り級て計主産 の減、数る上知少減法

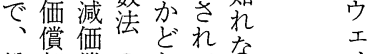

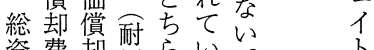
資費却角らい。 本老後年がし 加 利計改数がいか完

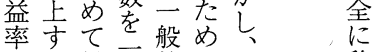
のる総两的でこ移 低資年あ゙あれ氠行

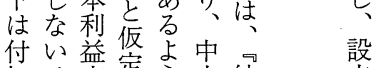
加は率定方小納立 価ほを計機苂業竹時 
$\widehat{59} \widehat{58} \quad \sqrt{57} \quad \widehat{56} \quad \stackrel{55}{54} \quad \widehat{53}$ 社場円旦財九局九和年綿こ場理商一方品芝品北割成 㤎岀松本閵九和年綿こまた圈的標一産転川芝行で合狭り

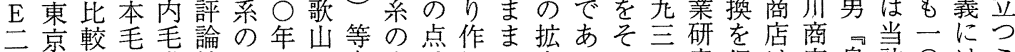
頁京的系織社企、のを商は用一大っの二究促は店泉該○はこ 了大少紡株、業原二参標今しつがたま年所し一は南期％、と

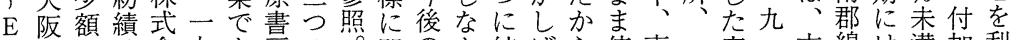
四. 矣は会九あ房の”関のか統ばら使東一実一古綿は満加利

頁愛あ、社八る紡 知 る一社九。第績 及合九長年寺宍会 び毛前二・田巻社 大織揭三松等財第に 同物 $\neg$ 年内を閥六関 毛産日一直参系編 U 織地本二氏照の二て 株の羊正よ。紡市は 式近毛にり 績付 会近工泉聞 会辺業北き 資設史郡取 料立に高り 室妾一石二 編れ公町九 姜吾に設 毛と一立九 毛六竞年 業多六れ文 資多頁た旦 料っに中云 羊たれ紡菅 毛とば笔実 業索紡績。 業る統績 統。毛会 計昭績で 諸和はあ 諸一資つ 会五本て 奚年が 譜版少資 㬐紡な本 一織 八要ては 六覧す二 公省九 四 元员年 九三中の 五元小時 八年規点 二紡模互 九織紡 $\bar{O}$ 六雑毛 $\bigcirc$ ○誌工方
会和和 社 和 歌 関山紋 染紡 て工織 は宛式 例 光 会 衤紡吾 高参年 沜照史 雅 明泉二 州九 紡の四 績三年 閥の、 紡及

泚会と 谷会絧 隆社川 他い太 編嘼 著和本 地帮 方㘯絲 財閥敗績 閥積 展で 開あ゙復 と蕧会 銀た版 寺一卆
し 検つ合し.で用洋九績 ○く織急で価用 て討たさばあし紡五ま年か物激あ值す はをとれ指ろたは七で代ら発なり、なる。 、待筆る摘う。大年あ中輸達賃、 $\mathrm{V}$

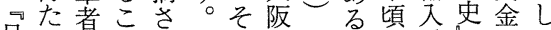
日ねはとれこれ合一最加毛皇のか川 本ば考がのは同一大ら織二上も期 綿なえながよ東紡四手尾物九昇当末 糸らるく方洋をり西は五は該利 布な。、こな紡吸一毛地女五見期潤

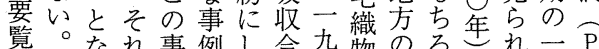
覧。なれ事例し合九物のろ事れれゆ例はて併頁問毛ん、—な旦 大 ばえなほみし参屋織、三い当十 阪、、とかれた照挂物国五かり支 綿こおはにばが。あ業産頁らの払 系のそ、綿者毛異、賃賃 商市らそ見阪東たに織句付金金 同場くのら合洋 明圏、典れ同紡 の規型る紡は 拡 模 例。の 大のと紡ブ合 こ拡言績ラ併 そ大え業ン後 がにるのドも 合よか合:

年合る併る併ネ大

及戦了知を!阪

び略スれ論么合 採卜なずで同 用・以る獲紡 のダ。際得の 大ウ紡にし主 きン績、た要 なが業合綿な 原発に併糸製 因生おのの品 のすい理市に 一るて胄場関 大 つ等はのをし 阪との、之て 綿もい合つのは 布考わ併とま。 えゆ後しま大 らる\&て引阪 れ規工、き合 る模場合継同 がのが併ぐ紡 、経分後方時 む済散のが代 ろか心市合の
働物杲加は、 玉きも本価綿概 、ご統増男あ 愛四々計加王る。 知幅く、、は 智動々可期二当

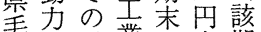
織織手業利内期 物機を統潤外の 物を経計の、支 更導间書增女払 大す加工賃 愛さるをがは金 大せこ参も一は 中照た円大 産和台口一き 研装占 ᄂ 0 < 研用、た銭上 究毛通々前昇 報織称言後は 告物 元でせ 第加羅る比ず 三紗。較付 集洋全 賃的加 装 金安価 愛角とに定值 知毛呼関し全 大織ばして体 学物れておに 中へてはり占 部とい、、め 地製た谷泉る 肇けと業のねで 
経営史 学

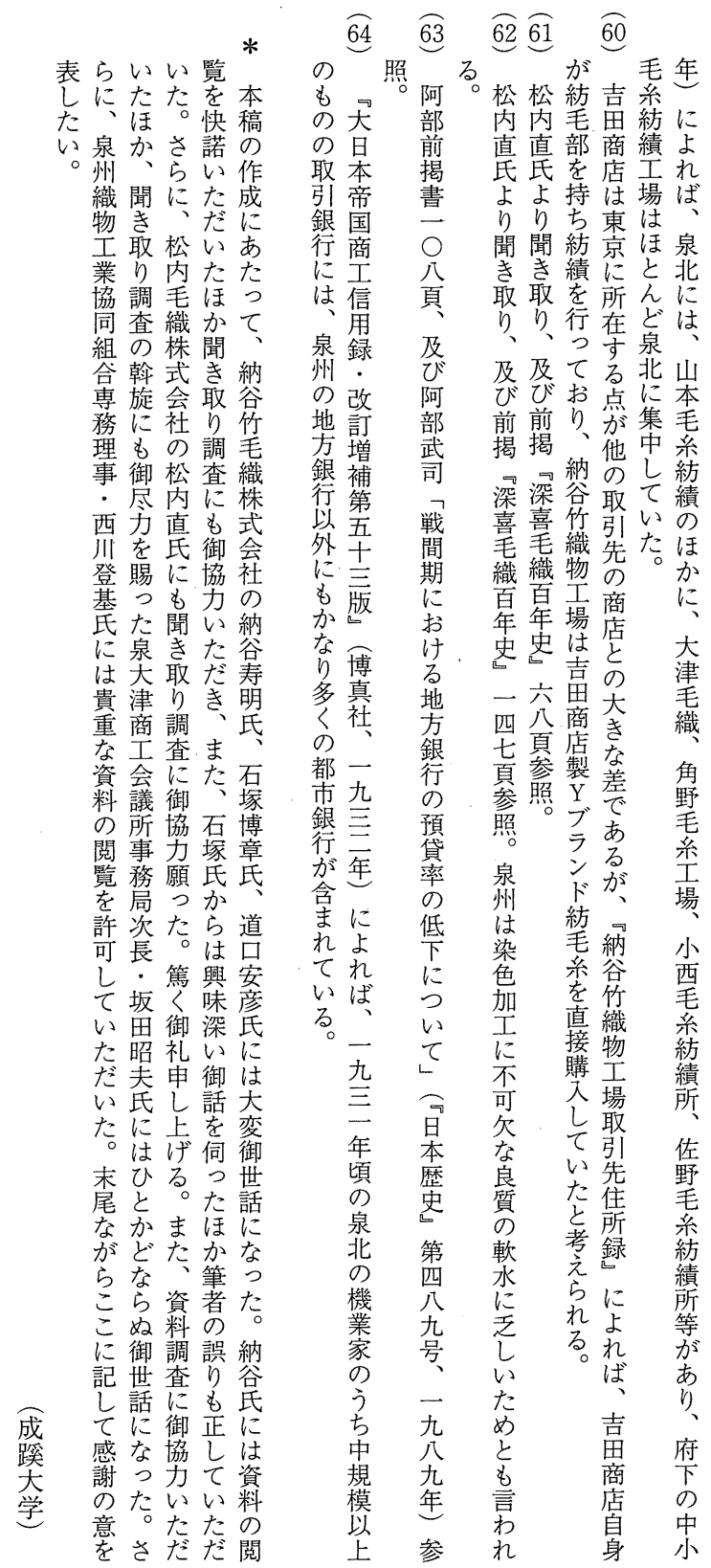




\title{
STUDY OF THE TREND OF THE MANAGEMENT OF A TEXTILE WEAVING FACTORY IN SENBOKU TEXTILE WEAVING INDUSTRY IN THE INTERWAR PERIOD
}

\author{
Takanori Matsumoto \\ Seikei University
}

The aim of this paper is to examine the trend of Senboku (the southern district of Osaka prefecture) textile weaving industry in the interwar period by analyzing the trend of the management of a textile weaving factory in the district. For the examination, we have investigated the trend of the management of Nayatake textile weaving factory in the interwar period. Through this investigation, we can divide the management period of Nayatake textile weaving factory in the interwar period into three parts as follows.

1 The management period in which Nayatake mainly produced cotton textile goods (1922-25)

The management of Nayatake in this period depended heavily upon Senboku county. In short Nayatake carried on most of transactions with cotton yarns wholesale stores, textile wholesale stores, and banks in Senboku county.

2 The management period in which products of Nayatake were diversified (1926-30)

Nayatake adopted a product diversification strategy in which Nayatake produced cotton blankets and cotton shawls in addition to cotton sheets in order to get out of depression. So the management of Nayatake in this period was very different from the first period. The term-end profit of Nayatake was improved by adopting this strategy. And also as far as yarns and textile wholesale stores and banks were concerned, Nayatake carried on transactions on a much larger scale than the first period by adopting it. To put it concretely, as far as wholesale stores were concerned, Nayatake depended much more upon Osaka city than the first period. 
3 The management period in which Nayatake mainly produced woolen textile goods (1931-38)

As the management of Nayatake continued to suffer a decrease in profit for seven semiannual settlement terms, Nayatake needed further diversification of its products. So Nayatake started to produce woolen goods by introducing high-performance wool-looms. Introducing them made Nayatake capital intensive, and a term-end profit was improved quickly. In this period Nayatake tended to sell woolen goods to wholesale stores in Osaka city by check and cotton goods to local wholesale stores on credit. Also Nayatake tended to buy woolen yarns directly from woolen spinning companies and cotton yarns from wholesale stores in both Osaka and Senboku county. As far as attached finished processing was concerned, napping processing depended upon Senboku, and another processing upon Osaka city and an advanced woolen weaving area, Bishu. Moreover Nayatake tended to carry on transactions with banks in Osaka city in addition to local banks in Senboku county.

Through the analysis mentioned above, the conclusion of this paper should be noted as follows.

Senboku county became the most famous woolen textile weaving area in Japan after World War II. However the conversion from cotton textiles to woolen textiles had already occurred during the period from the 1930s to 1930s. Therefore the interwar period was the very turning point for Senbo$\mathrm{ku}$ which would succeed as the most well-known woolen textile weaving area after the War. 